\title{
Collapsing Corporate Structures: Resolving the Tension Between Form and Substance
}

\author{
By Steven L. Schwarcz*
}

Courts, legislatures, and policymakers constantly must ask: when is a corporate structure legitimate, and when should it be collapsed? Although most urgent in the context of widespread but increasingly complex structured finance transactions which utilize multiple corporate entities as part of an overall structure, ${ }^{1}$ the question also arises in other important corporate contexts, including piercing the corporate veil (regarded as "one of the most litigated areas in American corporate law"), ${ }^{2}$ substantive consolidation, recharacterizing sales as transfers intended for security, and collapsing leveraged buyout ("LBO") transactions. In a larger sense, it is one of the most fundamental questions in corporation law, at the basis of any finding that the private ordering of a firm —or of the relationship between firmsis unenforceable or that the law should disrespect form in favor of substance. That is the question this Article engages.

\section{INTRODUCTION}

In isolated contexts, judges and scholars have attempted to formulate rules for determining when to collapse or recharacterize corporate structures. They have

\footnotetext{
* Steven L. Schwarcz is the Stanley A. Star Professor of Law \& Business, Duke University School of Law; and Founding Director, Duke Global Capital Markets Center. The author's email address is: schwarcz@law.duke.edu. The author thanks Bill Bratton, J. William Callison, Ralf Michaels, Peter Pantaleo, Robert Rasmussen, Barak Richman, Larry Ribstein, Daniel B. Schwarcz, Randall S. Thomas, and participants in an Early-Stages faculty workshop at Duke University School of Law, a Law and Business Workshop at Vanderbilt University Law School, and the 2004 Annual Conference of Commercial Law Teachers of Australia and New Zealand, The Australian National University Faculty of Law, for helpful comments, and Richard ("Chris") Beatty, Wyatt E. Bloomfield, Brian Brook, Richard Griffin, Adam Pyonin, and Paul M. Schoenhard for excellent research assistance. This research was supported by the Eugene T. Bost, Jr. Research Professorship of the Charles A. Cannon Charitable Trust No. 3. The author dedicates this Article to the memory of Justin Lord Coleman. The author was privileged and honored to be his mentor.

1. See, e.g., Steven L. Schwarcz, Enron and the Use and Abuse of Special Purpose Entities in Corporate Structures, 70 U. CIN. L. Rev. 1309, 1314-15 (2002) [hereinafter Schwarcz, Enron and the Use and Abuse of Special Purpose Entities in Corporate Structures) (discussing structured finance's use of multiple special-purpose corporate entities, or SPEs_-sometimes referred to as SPVs). References in this Article to "corporate" structures or entities mean structures or entities composed of one or more corporations, limited liability companies (LLCs), partnerships, and/or other separately identifiable non-natural bodies.

2. Handel C. H. Lee \& David M. Blumental, Parent Company and Shareholder Liability: "Piercing the Veil" of Chinese Corporate Subsidiaries, 5 Bus. L. INT'L 221, 223 (2004) (citing Robert B. Thompson, Piercing the Corporate Veil: An Empirical Study, 76 CORNELl L. REv. 1036, 1036 (1991)).
} 
not, however, seen the question as cutting across isolated doctrines. Nor have they attempted to formulate rules of general application, much less an overall theory from which to derive such rules.

This failure leaves the law with unsettling ad hocery, which in turn creates uncertainty and inefficiency. For example, any legal rule that enables the collapsing or recharacterizing of a transaction in order to respect "substance" over "form" will make parties much less likely to engage in the transaction, and may even deter parties from entering into similar transactions altogether ${ }^{3}$ When economically beneficial transactions are prevented, all parties suffer. ${ }^{4}$

The failure also creates multiple levels of inconsistency. ${ }^{5}$ It is difficult, for example, to distinguish cases in which a court collapses an LBO transaction by viewing it overall as a "black box" —examining only the starting and ending points of the transaction and ignoring the interim steps ${ }^{6}$-from the reluctance of courts to recharacterize structured financing transactions that, similarly viewed, ${ }^{7}$ would be seen as loans. ${ }^{8}$ Furthermore, even within doctrinal categories, the cases are often irreconcilable. ${ }^{9}$

This Article attempts to reconcile these disparate rules, to inquire into the normative justifications for formulating rules that collapse or recharacterize corporate structures, to fundamentally ask: when should the law respect, and when

3. See Douglas G. Baird \& Thomas H. Jackson, Fraudulent Conveyance Law and Its Proper Domain, 38 VAND. L. REV. 829, 834 (1985) ("The power of creditors to set aside transactions after the fact limits the ability of debtors to engage in the transactions in the first instance.").

4. See id. at 855 ("The uncertainty such a rule imposes makes debtors and creditors as a group worse off.").

5. For a discussion of the importance of consistency in a commercial law system, see Steven $L$. Schwarcz, A Fundamental Inquiry Into the Statutory Rulemaking Process of Private Legislatures, $29 \mathrm{GA}$. L. REv. 909, 940-44 (1995) [hereinafter Schwarcz, A Fundamental Inquiry Into the Statutory Rulemaking Process of Private Legislatures].

6. See infra Part II.D.

7. I attempt to distinguish these cases, however, in Part Ill.D, infra.

8. [In] a typical example from structured finance[,] [a] company settles a trust by transferring financial assets to the trust in return for payment in the form of trust certificates and a bargainedfor residual interest in the trust. The company then raises funds by selling the trust certificates to capital market investors, who buy the certificates expecting that the trust assets will generate sufficient cash to repay their investment plus the contractual rate of return specified in the certificates. The residual interest entitles the company to any assets remaining in the trust once the certificates are paid in full. In this way, the company does not give up more value than needed to make the deal work.

The deal is thus an arm's-length, negotiated bargain in which all parties benefit. The investors, as senior claimants of the trust, get their money back with interest. The company, as residual claimant, receives payment for the financial assets sold to the trust and is entitled to any residual value of those assets once the investors are paid in full. In economic terms, the deal is similar to a secured loan-the quintessential commercial transaction-in which surplus collateral is returned to the debtor once lenders receive principal and interest.

Steven L. Schwarcz, Commercial Trusts as Business Organizations: Unraveling the Mystery, 58 Bus. LAw. $559,562-63$ (2003) (emphasis added) (footnotes omitted).

9. See, e.g., Vincent M. Roche, "Bashing the Corporate Shield": The Untenable Evisceration of Freedom of Contract in the Corporate Context, 28 J. CORP. L. 289, 289 (2003) (observing that even the most developed of these doctrines, veil-piercing, is "usually stated in broad terms that offer little or no guidance to judges or litigants in subsequent cases, [thereby creating] a prime opportunity for courts to disturb, under the cover of the law's ambiguity, validly executed, freely negotiated agreements."); Thompson, supra note 2, at 1036-37 (same). 
should it disrespect, form over substance and the manner in which firms purport to structure their legal relationships?

To this end, the Article first examines and synthesizes existing sources of law on collapsing or recharacterizing corporate structures. ${ }^{10}$ Although the focus is primarily on U.S. law, many of the same considerations appear to be present in other common-law jurisdictions, ${ }^{11}$ as well as in at least some if not many civillaw jurisdictions. ${ }^{12}$ The synthesis reveals a range of judicial responses to related fact patterns. It also suggests that judges implicitly have been grappling with one of the most difficult conceptual problems of contract law: the circumstances under which externalities should defeat contract enforcement. ${ }^{13}$ By addressing that problem directly through contract theory and economics, this Article proposes a more systematic, consistent, and, arguably, conceptually satisfying approach to solving the problem of collapsing or recharacterizing corporate structures. ${ }^{14}$ Finally, the Article examines how this approach might inform, or be informed by, the related debate over whether limited liability should be the default rule in corporation law.

\section{EXISTING SOURCES OF LAW ON COLlapsing OR ReCharaCterizing Corporate Structures}

\section{A. Piercing the Corporate Veil}

The doctrine of "piercing the corporate veil" is a prime example of the tension between form and substance in the corporate-law environment. As a general rule, shareholders are not liable for corporate obligations, ${ }^{15}$ and thus parent-firms are not liable for the obligations of their subsidiaries. ${ }^{16}$ By respecting the corporate form, this rule facilitates the purpose for which corporate structures are created-

10. Recall that these sources of law include piercing the corporate veil, substantive consolidation, recharacterizing sales as transfers intended for security, and collapsing LBO transactions. See supra notes $1-2$ and accompanying text.

11. I say this based on feedback to a February 9, 2004 keynote speech on this Article that I gave at the 2004 Annual Conference of Commercial Law Teachers of Australia and New Zealand, held at The Australian National University Faculty of Law.

12. See Lee \& Blumental, supra note 2, at 226-29, 229-38 (discussing veil-piercing jurisprudence in Germany and China, respectively).

13. References herein to "externalities" mean negative externalities. See infra note 77 and accompanying text.

14. This Article addresses that problem in part by employing a two-step analysis: first, using a Kaldor-Hicks standard of efficiency for collapsing (inefficient) corporate structures; second, examining the extent to which, notwithstanding Kaldor-Hicks efficiency, corporate structures should be collapsed (or other remedies provided) in order to internalize externalities. This approach resolves the dilemma that using Kaldor-Hicks efficiency alone is inadequate, whereas using a Pareto efficiency standard would render any corporate structure with non-internalized externalities-effectively most corporate structures-inefficient. See infra notes 78-101 and 119-149 and accompanying text.

15. See, e.g., Frank H. Easterbrook \& Daniel R. Fischel, Limited Liability and the Corporation, 52 U. CHI. L. REv. 89, 89-90 (1985) ("The rule of limited liability means that the investors in the corporation are not liable for more than the amount they invest."). firms.

16. By "parent-firms," I mean firms that own a majority of the shares of, or otherwise control, other 
limitation of liability. ${ }^{17}$ Courts, however, may look through, or "pierce," the corporate form in order to assign subsidiary liability to shareholders and parent-firms in certain circumstances. ${ }^{18}$ The discussion below focuses on the relationship between subsidiaries and their parent-firms, but it could apply equally to the relationship between any shareholders - including individuals — and the firms in which they hold stock. ${ }^{19}$

Courts limit the remedy of piercing the corporate veil to situations where parent-firms so control and dominate their subsidiaries that corporate independence is lacking and the parent and its subsidiary are effectively alter egos. ${ }^{20}$ Even then, veil piercing is only appropriate where the subsidiary is improperly used, causing damage or harm - such as preventing the subsidiary's creditors from being repaid. ${ }^{21}$ For example, courts will sometimes pierce the corporate veil of an undercapitalized subsidiary to reach the parent-firm's assets (though undercapitalization alone appears to be an insufficient basis for piercing the veil) ${ }^{22}$ based on the following rationale:

If limited liability is absolute, a parent can form a subsidiary with minimal capitalization for the purpose of engaging in risky activities. If things go well, the parent captures the benefits. If things go poorly, the subsidiary declares bankruptcy, and the parent creates another with the same managers to engage in the same activities. This asymmetry between the benefits and costs, if

17. See Easterbrook \& Fischel, supra note 15, at 93-97 (explaining in detail the theory and rationale of limited liability). Indeed, some have argued that the modern corporation could not exist without limited liability. See Henry Manne, Our Two Corporation Systems: Law and Economics, 53 VA. L. ReV. 259,262 (1967).

18. See, e.g., Mobil Oil Corp. v. Linear Films, Inc., 718 F. Supp. 260, 268 (D. Del 1989) (piercing the corporate veil); David Stegman, Is it Ever Too Late to Add a Party?, 25 U. DAyIon L. Rev. 263, 264 (2000) ("Even if a corporation has been formed in accordance with the applicable statutory provisions, a court may pierce the corporate veil, refuse to recognize the corporate entity, and impose liability on individual shareholders for corporate debts.").

19. JAmes D. COX ET Al., CoRporations $§ 7.16$, at 299 (2d ed. 2003) ("Problems regarding [respecting or disregardingl the corporate entity frequently arise within the context of parent and subsidiary or between affiliated corporations. The same principles apply here as to individual shareholders and their corporations."); John A. Swain \& Edwin E. Aguilar, Piercing the Veil to Assert Personal Jurisdiction Over Corporate Affiliates: An Empirical Study of the Cannon Doctrine, 84 B.U. L. REv. 445, 447, 452 (2004) (same); also cf. Henry Hansmann \& Reinier Kraakman, Toward Unlimited Shareholder Liability for Corporate Torts, 100 YALE L.J. 1879, 1932 (1991) thereinafter Hansmann \& Kraakman, Toward Unlimited Shareholder Liability for Corporate Torts] (arguing, in the context of discussing veil piercing, that "any arbitrary line between corporations in which shareholders can be held personally liable ... and those in which they cannot-whether between subsidiaries and nonsubsidiaries or between closely-held and publicly-traded firms-will create unnecessary and costly problems.").

20. Mark A. Olthoff, Beyond the Form-Should the Corporate Veil Be Pierced?, 64 UMKC L. Rev. 311, 312 (1995); see also Cox, supra note 19, $\$ 7.08$, at 280-81; Steven L. Schwarcz, The Inherent Irrationality of Judgment Proofing, 52 STAN. L. REv. 1, 38 n.199 (1999) (hereinafter Schwarcz, The Inherent Irrationality of Judgment Proofingl.

21. Olthoff, supra note 20 , at 312 ; Cox, supra note $19, \S 7.8$ (arguing that the factors that justify piercing the corporate veil are the failure to observe proper corporate formalities, including the failure to maintain an arm's length relationship between the firm and its subsidiary, and the use of the subsidiary as a shell or conduit for risky transactions).

22. Thompson, supra note 2 , at 1038 
limited liability were absolute, would create incentives to engage in a socially excessive amount of risky activities. ${ }^{23}$

Professor White has attempted to loosely synthesize the doctrine of piercing the corporate veil: "Although the tests for veil piercing are hardly precise, their factors coincide more or less with the acts a parent would have to take to insulate itself from liability generated by a subsidiary."24 Even this statement, however, is overly broad as Professor White himself admits, because "corporations create subsidiaries to insulate themselves and other subsidiaries from some liabilities."25 Indeed, if any act taken by a parent to insulate itself from a subsidiary's liabilities were grounds for piercing the corporate veil, then the parent-subsidiary relationship often would be meaningless. ${ }^{26}$ The veil-piercing doctrine instead appears more limited: to avoid wrongful acts taken by a parent in order to insulate itself from liability generated by a subsidiary, where fairness and equity suggest that the obligations of the subsidiary be satisfied by the parent. ${ }^{27}$ Unfortunately, this subjective focus leads to inconsistencies in the manner in which the veil-piercing doctrine is applied, and may explain why the doctrine is so conceptually confusing. ${ }^{28}$

\section{B. Substantive Consolidation}

In a bankruptcy context, courts have devised a doctrine in some ways similar to piercing the corporate veil, referred to as "substantive consolidation." ${ }^{29}$ This is

23. Frank H. Easterbrook \& Daniel R. Fischel, The Economic Structure of Corporate Law 57 (1991). A subsidiary may be undercapitalized from its inception (see Pierson v. Jones, 625 P.2d 1085,1087 (Idaho 1981) (finding liability where a corporation was undercapitalized based on the "nature and magnitude of the corporate undertaking ... at the time of the inception of the corporation.") (emphasis removed)) because the parent has failed to infuse additional capital as necessary (see DeWitt Truck Brokers, Inc. v. W. Ray Flemming Fruit Co., 540 F.2d 681 (4th Cir. 1976)), or because the parent has drained the subsidiary of its assets (see, e.g., Eastridge Dev. Co. v. Halpert Assocs., Inc. 853 F.2d 772, 780 (10th Cir. 1988) (allowing a claim directly against the parent, where the parent acquired a subsidiary, cancelled its liability insurance, and drained the subsidiary of assets in order to thwart the claim of a tort creditor)).

24. James J. White, Corporate Judgment Proofing: A Response to Lynn LoPucki's The Death of Liability, 107 YALE L.J. 1363, 1401-02 (1998). This lack of precision is hardly limited to U.S. law. See, e.g., Lee $\&$ Blumental, supra note 2. "Chinese courts have been piercing the corporate veil for almost a decade, but unfortunately there is no established legal framework for extending liability to a company's shareholders." Id. at 222. "In piercing cases, PRC [Peoples Republic of China] courts often allude to the familiar themes of control or domination, undercapitalization, commingling of assets and disregard for corporate formalities, and deception or fraud. However, it is not clear which of these factors, or what combination of these factors, PRC courts find most persuasive." Id. at 231-32. "There is clearly a need for a more coherent piercing doctrine in China." Id. at 238.

25. White, supra note 24 , at 1399 .

26. Professor White's analysis focuses, however, on why liabilities cannot be reduced to zero. See id.

27. See, e.g., Olthoff, supra note 20 , at 318 (requiring the plaintiff to prove that "unless the corporate veil is pierced, it will have been treated unjustly by the defendant's exercise of control and improper use of the corporate form and, thereby, suffer damages."); Cox, supra note $19, \S 7.08$, at 276 ("The facts presented [for veil piercing] must demonstrate some misuse of the corporate privilege or establish a need to limit it in order to do justice.").

28. Cf. Swain \& Aguilar, supra note 19, at 451 (observing that "[d]iscerning the precise contours of [veil] piercing doctrine is notoriously problematic.").

29. See In re Cont'l Vending Mach. Corp., 517 F.2d 997, 1000 (2d Cir. 1975) (noting the similarities between piercing the corporate veil and substantive consolidation). 
an equitable doctrine under which bankruptcy judges can disregard the corporate form by ordering "pooling of the assets and liabilities of two or more related entities." As a result, "the liabilities of the entities involved are then satisfied from the common pool of assets created by consolidation." 31

Substantive consolidation requires, as a minimum, a substantial breakdown of corporate formalities between the firms being considered for consolidation. ${ }^{32}$ In such cases, creditors or shareholders of those firms can ask the court to consider whether substantive consolidation is appropriate. ${ }^{33}$ Though within the court's discretion, that determination is not taken lightly. Besides representing a repudiation of corporate-contractual arrangements, substantive consolidation can dramatically affect the rights of litigants..$^{34}$ For example, the debt-equity ratio of a substantively consolidated firm would only coincidentally equal the debt-equity ratio of each constituent firm prior to the consolidation. Substantive consolidation will thus benefit creditors of higher debt-equity ratio firms at the expense of creditors of lower debt-equity ratio firms. ${ }^{35}$

Accordingly, any decision to substantively consolidate two or more firms additionally requires the court to weigh the benefits of consolidation against any harm to objecting creditors. ${ }^{36}$ Only where those benefits heavily outweigh the harm is substantive consolidation appropriate. ${ }^{37}$ Substantive consolidation is thus

30. Eastgroup Props. v. S. Motel Ass'n., Ltd., 935 F.2d 245, 248 (1lth Cir. 1991); see also Mary Elisabeth Kors, Altered Egos: Deciphering Substantive Consolidation, 59 U. PITT. L. REv. 381, 381 (1998) (defining substantive consolidation as "the effective merger of two or more legally distinct (albeit affiliated) entities into a single debtor with a common pool of assets and a common body of liabilities.").

31. Eastgroup Props., 935 F.2d at 248.

32. Id. at 249 (requiring the proponent of substantive consolidation to show "there is substantial identity between the entities to be consolidated"); see also In re Vecco Constr. Indus., Inc., 4 B.R. 407 , 410 (Bankr. E.D. Va. 1980); 5 William Miller Collier, Collier on BANkruptCy 9 1100.06[3] (Lawrence P. King ed., 15th ed. 1989 \& Supp. 1996); Chem. Bank N.Y. Trust Co. v. Kheel (In re Seatrade Corp.), 369 F.2d 845, 847 (2d Cir. 1966); In re Manzey Land \& Cattle Co., 17 B.R. 332, 338 (Bankr. D.S.D. 1982). These cases list such factors as the degree of difficulty in segregating and ascertaining individual liabilities and assets; the presence or absence of consolidated financial statements; the commingling of assets and business functions; the unity of ownership and interests between the corporate firms; the guaranteeing by the parent firm of loans of the subsidiary; and the transfer of assets without formal observance of corporate formalities. The presence of some or even many of these factors does not necessarily mean, however, that a court will order a substantive consolidation.

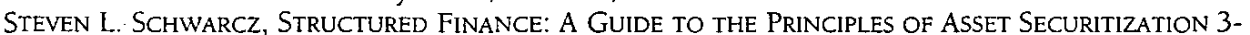
23 (3d ed. 2003) [hereinafter Structured FinAnCE].

33. See, e.g., In re Augie/Restivo Baking Co., Ltd., 860 F.2d 515, 516 (2d Cir. 1988).

34. Id. at 518 ("[W]e have stressed that substantive consolidation "is no mere instrument of procedural convenience ... but a measure vitally affecting substantive rights'") (quoting Flora Mir Candy Corp. v. R.S. Dickson \& Co., 432 F.2d 1060, 1062 (2d Cir. 1970)).

35. Jeffrey E. Bjork, Seeking Predictability in Bankruptcy: An Alternative to Judicial Recharacterization in Structured Financing, 14 BANKR. DEV. J. 119, 138 (1997); see also In re Auto-Train, Corp., 810 F.2d 270, 276 (D.C. Cir. 1987) (observing that because the entities to be consolidated are likely to have different debt-equity ratios, substantive consolidation "almost invariably redistributes wealth among the creditors of the various entities.").

36. See, e.g., Schwarcz, The Inherent Irrationality of Judgment Proofing, supra note 20, at 37 (discussing judicial discretion to order substantive consolidation as a means of limiting "judgment proofing"). In the Second Circuit, substantive consolidation is even stricter, requiring that no innocent creditors be harmed. Augie/Restivo Baking Co., 860 F.2d at 519.

37. Eastgroup Props., 935 F.2d at 249; Auto-Train, Corp., 810 F.2d at 276. 
generally disfavored, though the recent trend has been to allow it more liberally in response to increasingly complex corporate structures. ${ }^{38}$

\section{RECHARACTERIZING SALES AS TRANSFERS INTENDED FOR SECURITY}

The tension between form and substance also arises in the context of securitization transactions. These are transactions in which the firm originating the transaction (the "originator") contracts to sell financial assets, such as accounts receivable, loans, or lease rentals, to a bankruptcy-remote special-purpose vehicle ("SPV"), which in turn raises money from capital market investors ${ }^{39}$ on the strength of those financial assets. ${ }^{40}$

In form, securitization transactions are contractually-arranged sales of financial assets. In economic substance, however, they are not dissimilar to transfers intended as security (i.e., loans secured by the financial assets). ${ }^{41}$ This disparity between form and substance is central to the most critical issue in a securitization: whether the transfer of financial assets from the originator to the SPV is, in fact, a "true sale"-meaning that the transfer has effectively removed those assets from the originator's estate to become property of the SPV for bankruptcy purposes. If the transfer is not a true sale, it is deemed to be merely a loan secured by the financial assets; and the SPV then may be unable to obtain payments collected on those assets until the end of the bankruptcy case. ${ }^{42}$ That inability would hurt the SPV's investors, although it would likely help the originator and its creditors.

For this reason, courts concerned about the originator or its creditors sometimes find that the transfer of financial assets is not actually a true sale, recharacterizing it instead as a secured loan. ${ }^{43}$ The law governing such recharacterization is not, however, well settled. ${ }^{44}$ To the extent coherent case law has developed,

38. Eastgroup Props., 935 F.2d at 248-49.

39. The capital markets are "markets where capital funds-debt and equity-are traded. Included are private placement sources of debt and equity as well as organized markets and exchanges." JOHN Downes \& Jordan Elliot GOOdMan, Dictionary of FinanCE and Investment Terms 59 (3d ed. 1991).

40. The details are actually more complicated, though unnecessary to this Article's analysis. After purchasing the financial assets, the SPV transfers such assets to a second SPV. The second SPV then issues securities to the capital market investors and uses the proceeds of the issuance to pay the first SPV for the financial assets. The first SPV then uses those proceeds to pay the originator. See Steven L. Schwarcz, Securitization Post-Enron, 25 CARDOzo L. REV. 1539, 1540 (2004) [hereinafter Schwarcz, Securitization Post-Enron] (symposium issue on "Threats to Asset-Based Finance"). The investors in the securities are repaid from collections of the financial assets, and therefore buy the securities based on their assessments of the value of those assets. Id. For a more complete discussion of securitization, including these transactional steps, see STRUCTURED FINANCE, supra note 32; Schwarcz, The Inherent Irrationality of Judgment Proofing, supra note 20, at 6; Steven L. Schwarcz, The Alchemy of Asset Securitization, 1 STAN. J. L. Bus. \& FIN. 133, 135-36 (1994).

41. See supra note 8 and accompanying text (observing that, in economic terms, securitization deals are similar to secured loans).

42. StRUCTURED FinANCE, supra note 32, at 4-3 (discussing the automatic stay in bankruptcy and other consequences of recharacterization).

43. Id. at 4-4 (discussing such recharacterization in the In re LTV Steel Co. case)

44. See id. at 4-5. "Although various courts have considered whether a given transfer of [financial assets] constitutes a sale or a secured loan for bankruptcy purposes, the facts of the decided cases 
a cluster of factors can be identified that are relevant in most determinations of whether a given transfer of [financial assets] is a sale or a secured loan. Each of these factors is indicative of whether the originator truly parted with the future economic risks and benefits of ownership of the [assets] purported to be sold, and whether the SPV has taken on those risks and benefits. ${ }^{45}$

This determination, however, can be highly subjective. ${ }^{46}$

\section{Collapsing lBo Transactions}

Courts again confront the tension between form and substance when examining failed LBO transactions. ${ }^{47}$ In an LBO, a group of investors, sometimes associated with the management of the firm being acquired, takes control of that firm (the "target firm") by indirectly causing it to borrow and using the proceeds to purchase

have not been representative for the most part of modern asset-securitized transactions. Accordingly, the cases are not easily harmonized, and different readers can argue as to which factors are relevant and which are entitled to the greater weight." Id. Indeed, recent legislative attempts have sought to formalize the notion of true sale. Prior to the Enron debacle, section 912 of the then-pending Bankruptcy Reform Act of 2001 would have created a "safe harbor" for true sales in securitization transactions; but this provision was deleted post-Enron. See Schwarcz, Securitization Post-Enron, supra note 40, at 1542 n. 14; see also Steven L. Schwarcz, The Impact of Bankruptcy Reform on "True Sale" Determination in Securitization Transactions, 7 FORDHAM J. CORP. \& FIN. L. 353, 353-54 (2001). More recently, Sen. Dick Durban and Rep. William Delahunt introduced legislation that would authorize bankruptcy judges to "recharacterize as a secured loan, a sale . . . if the material characteristics of the sale ... are substantially similar to the characteristics of a secured loan." $\$ .2798,107$ th Cong. $§ 102$ (2002). This legislation also was withdrawn, though similar legislation may be introduced at a future date. See Securitization Post-Enron, supra note 40, at 1542 n. 18.

45. StRUCTURED FinANCE, supra note 32 , at 4-5.

46. For example, one of the primary factors identified is the amount and nature of the SPV's recourse against the originator in the event the financial assets lose value; a true sale is thought to transfer substantive risk on those assets from the originator to the SPV. Id. However, even though "securitization deals do shift actual risk, they always require the company originating the deal to retain sufficient first-loss risk on the transferred assets, usually in the form of 'overcollateralization,' to minimize the investor risk to an investment grade level." Schwarcz, Enron and the Use and Abuse of Special Purpose Entities in Corporate Structures, supra note 1, at $1316 \mathrm{n} .38$ (arguing that the originator should retain the first-loss risk because of the asymmetric information between the originator and the SPV's investors). First-loss risk can be easily distinguished, however, from Enron's SPV transactions, in which virtually all risk was placed on Enron itself. See William C. Powers, Jr. et al., Report of Investigation by the Special Investigative Committee of the Board of Directors of Enron Corp. 36-37 (Feb. 1, 2002); Steven L. Schwarcz, Rethinking the Disclosure Paradigm in a World of Complexity, 2004 U. ILL. L. REV. 1, 2 (2004); see also Senate Permanent SubCOMm. ON InVESTigations, RePORT ON Fishtail, Bacchus, SUNDANCE, AND SLAPSHOT: FOUR ENRON TRANSACtIONS Funded ANd FaCILITATEd By U.S. FinanCiaL INSTITUTIONS, S. REP. NO. 107-82, at 2 (2003), available at http://govt-aff.senate.gov/010203psireport. pdf (last visited Oct. 19, 2004).

47. Although LBO transactions have waned in popularity since their heyday in 1980's, they are ałways liable to return to prominence if shareholder value becomes depressed. Lee Hammer, Turning a Blind Eye: The Ninth Circuit's Approach to Fraudulent Conveyances and Leveraged Buyouts, $31 \mathrm{SW}$. U. L. REv. 237, 242 (2002) (noting that "[a]lthough the new mantra of the corporate world is 'merger' and not 'leveraged buyout,' this scenario could change if the stock market falters and depresses the value of shareholder equity."). 
its stock. ${ }^{48}$ The target firm's shareholders benefit by being bought out at a premium. ${ }^{49}$ The investor group benefits where, as is typical, the value of the target firm exceeds its market capitalization. ${ }^{50}$ And formally the target firm receives adequate consideration for each independent transaction. ${ }^{51}$ An LBO transaction thus might appear immune to challenge.

Nonetheless, LBOs can impair claims of the target firm's existing creditors. The borrowed funds add to the target firm's overall debt burden without increasing its assets, ${ }^{52}$ and in many cases existing claims are also effectively subordinated to claims of the LBO lender (which are secured by the assets of the target firm) ${ }^{53}$ If the target firm becomes insolvent or goes bankrupt, existing creditors are prejudiced. ${ }^{54}$ Non-adjusting creditors, ${ }^{55}$ of course, cannot protect themselves because they cannot bargain for interest to offset any increase in risk..$^{56}$ Although contractual creditors theoretically can protect themselves by requiring loan covenants restricting their debtor firms from engaging in LBO transactions, experience has shown that such creditors generally choose higher interest rates, which may or

48. In a typical LBO, for example, the acquisition-minded investors create a single-purpose "shell" company, with no assets or liabilities. After obtaining a commitment from lenders to borrow sufficient funds to purchase the shares of stock of the target firm, the shell company makes a tender offer for those shares. The shell company pays for the purchased shares by drawing down on the loan commitment. After purchasing those shares, thereby acquiring the target firm as a subsidiary, the shell company causes the target firm to merge into itself. The merged entity is then given the name of the target firm and pledges its assets to the LBO lenders to secure repayment of their loans. See Steven L. Schwarcz, Rethinking a Corporation's Obligations to Creditors, 17 CARDOzo L. Rev. 647, 685 (1996) [hereinafter Schwarcz, Rethinking a Corporation's Obligations to Creditors]; Sarah B. Foster, Let's Remake a Deal: Fraudulent Transfer Laws As a Tool for Restructuring Leveraged Buyouts 297, 303 (PLI Commercial Law \& Practice Course, Handbook Series No. A4-4408, 1993), available at WL 649 PLVComm 297.

49. Schwarcz, Rethinking a Corporation's Obligations to Creditors, supra note 48, at 685 .

50. For an informative though cynical view of this benefit, see Benjamin J. Stein, Shooting Fish in a Barrel-Why Management Always Makes a Bundle in an LBO, BARRON's, Jan. 12, 1987, at 6 .

51. See Foster, supra note 48, at 316 (noting that "[o]n its face, the [Tabor Court Realty Corp. LBO] transaction appeared to be for fair consideration; mortgages were given in return for money."); Kevin J. Liss, Fraudulent Conveyance Law and Leveraged Buyouts, 87 CoLUM. L. REV. 1491, 1497-98 (1987) (describing typical steps in an LBO).

52. Liss, supra note 51 , at 1498-99 ("What benefits, if any, the target receives cannot readily be discerned. To the extent that any benefits do accrue to the target, they are at most subsequent and indirect."); Schwarcz, Rethinking a Corporation's Obligations to Creditors, supra note 48, at 685; Foster, supra note 48 , at 303 ("Often, the only change in the target is that it suddenly has to service large amounts of new secured debt.").

53. Foster, supra note 48 , at 303.

54. LBO transactions can impair the value of existing claims even where the target firm remains solvent, by increasing the target firm's debt-equity ratio and prompting rating agencies to reduce its bond ratings. See Metro. Life Ins. Co. v. RJR Nabisco, Inc., 716 F. Supp. 1504, 1520 (S.D.N.Y. 1989). Whether that impairment of value is, or should be, an externality recognized by law is beyond the scope of this Article.

55. Non-adjusting creditors include involuntary creditors, such as tort creditors, as well as voluntary creditors that, for whatever reason-e.g., they extend credit on fixed terms or, like some trade creditors, their claims are so small that it is impractical to monitor-cannot adjust their interest rates. Lucian Arye Bebchuk \& Jesse M. Fried, The Uneasy Case for the Priority of Secured Claims in Bankruptcy, 105 YALE L.J. 857, 869-70 (1996).

56. See, e.g., United States v. Tabor Court Realty Corp., 803 F.2d 1288, 1297 n.2 (3d Cir. 1986), cert. denied, 483 U.S. 1005 (1987) (a case "in which the major creditors (in this instance the United States and certain Pennsylvania municipalities) are involuntary and do not become creditors by virtue of a contract."). 
may not be a sufficient quid pro quo, to omit such covenants. ${ }^{57}$ Moreover, where the structure of the LBO, or an innovation based thereon, is novel, even otherwise adjusting creditors cannot always anticipate, and therefore may be unable to adjust for, the deal type. ${ }^{58}$

At least one court has collapsed a failed LBO transaction. In United States $v$. Tabor Court Realty, ${ }^{59}$ the U.S. Court of Appeals for the Third Circuit held that the LBO loan and subsequent payment of the loan's proceeds to shareholders were "part of one integrated transaction." 60 Thus, the "loan proceeds ... were merely passed through the [target firm to its shareholders] and cannot be deemed consideration received by the [target firm.]"61 Because the LBO lender "knew, or should have known, that the money it lent ... was used, in part, to [pay the target firm's] shareholders," 62 the court used fraudulent conveyance law to invalidate the mortgage granted to the LBO lender. ${ }^{63}$

Though other direct precedents are rare, the Tabor Court Realty decision has been viewed by many as mainstream law and not an aberration. ${ }^{64}$ The decision, however, is not completely free from criticism. ${ }^{65}$

57. Larry Light, Bondholder Beware: Value Subject to Change Without Notice, Bus. WK., Mar. 29, 1993, at 34 (describing the situation after Marriott Corporation split itself into two parts, causing disgruntled bondholders to sue and call for more restrictive bond covenants to prevent other companies from taking similar actions: "Bondholders can-and will-fuss all they like. But the reality is, their options are limited: Higher returns or better protection. Most investors will continue to go for the gold.").

58. See, e.g., Tabor Court Realty Corp., 803 F.2d at 1297 n.2 (discussing "the possibility that the creditors attacking the leveraged buy-out (such as many of the creditors in this case) became creditors before leveraged buy-outs became a common financing technique and thus may not have anticipated such leveraged transactions so as to have been able to adequately protect themselves by contract.").

59. Id. at 1288 .

60. Id. at 1302

61. Id. Although the court's ruling is limited to Pennsylvania's enactment of the Uniform Fraudulent Conveyance Act, the court emphasized that Act's similarity to federal fraudulent conveyance law. Id. at $1298-99$.

62. Id. at 1295 (affirming the lower court's finding to this effect); see also id. at 1296 (finding that the LBO lender "was aware, first, that the exchange would render Raymond insolvent, and second, that no member of the Raymond Group would receive fair consideration.").

63. Accord Lippi v. City Bank, 955 F.2d 599, 606-07 (9th Cir. 1992) (holding that whether LBO transactions can be collapsed as fraudulent is determined, on a case-by-case basis, by whether the parties knew or should have known about the use of proceeds). For further background on fraudulent conveyance law, see Liss, supra note 51, at 1497-98, and Steven L. Schwarcz, The Impact of Fraudulent Conveyance Law on Future Advances Supported by Upstream Guaranties and Security Interests, 9 CARDOzO L. REV. 729 (1987).

64. Margaret Howard, Vern Countryman and Barry Zaretsky: A Legacy of Ideas, 75 AM. BANKR. L.J. 283, 289 (2001) ("[B]y 1990, most courts had accepted the applicability of fraudulent conveyance law to leveraged buyouts").

65. See Baird \& Jackson, supra note 3 , at $835,854-55$ (arguing against applying fraudulent conveyance law to LBO transactions because the creditor relationship is largely contractual and thus creditors can protect themselves from LBOs through terms within their contract (id. at 835), and also because LBOs are largely efficient and thus should not be discouraged (id. at 854-55)). The Ninth Circuit has been most receptive to these arguments and has yet to fully apply fraudulent conveyance laws to LBOs. See Hammer, supra note 47, at 240-41. Although I agree that LBOs can be efficient, Professors Baird and Jackson largely ignore potential harm to non-adjusting creditors and possibly also to adjusting creditors. See supra notes $55-58$. 


\section{E. SYNTHESIS}

All of these doctrines espouse substance over form, but they also share three other common traits: they are judicially-created doctrines; they respond to material improprieties in a corporate arrangement; and they challenge that corporate arrangement to the extent it creates externalities by shielding assets from thirdparty (usually creditor) claims. The challenge appears most robust where, as in the cases of piercing the corporate veil and collapsing LBO transactions, the corporate arrangement shields assets of a party causing the improprieties.

For example, the doctrine of piercing the corporate veil collapses corporate walls that shield parent-firm assets from claims of a subsidiary's creditors, where the subsidiary lacks real corporate independence and is misused by the parentfirm. The doctrine of substantive consolidation collapses corporate walls that shield an affiliate's assets from claims of a firm's creditors and shareholders, where there is a substantial breakdown of corporate formalities between the firms being considered for consolidation (though this doctrine requires the further finding that the benefits of consolidation heavily outweigh any harm). The doctrine of recharacterizing sales as transfers intended for security challenges inter-firm contracts that shield transferred assets from claims of creditors of the transferor, where the transferor has not truly parted with, and the transferee has not taken on, the future economic risks and benefits of ownership of the transferred assets. And the doctrine of collapsing LBO transactions challenges inter-firm contracts that shield assets of the target-company from its creditors' claims, where the LBO renders the target-company insolvent and thus unable to pay its creditors and the LBO lender knew or should have known of that potential outcome.

Furthermore, all of these doctrines are simply means of collapsing or recharacterizing the contractual arrangements that form the corporation. This follows from the nexus-of-contracts theory of corporations, under which:

the corporation [is] a bundle of market-driven actual and hypothetical bargains among shareholders, managers, and other firm participants, including outside third parties that deal with the firm. Neither corporations nor their shareholders are thought of as having external moral or social obligations independent of contract-the corporation because it is not a person, and the shareholders because they do not contract for broader responsibilities. ${ }^{66}$

Although the doctrines of piercing the corporate veil and substantive consolidation are different from the doctrines of collapsing LBOs and sale recharacterization insofar as the type of contract affected, that difference should not affect this Article's analysis. ${ }^{67}$

66. J. William Callison, Rationalizing Limited Liability and Veil Piercing, 58 BUS. LAw, 1063, 1065 (2003). Accord Easterbrook \& Fischel, supra note 15, at 89.

67. The doctrines of piercing the corporate veil and substantive consolidation are used to collapse the walls around corporate structures-treating firms A and B, each with separate creditors, as a single firm against whose assets those creditors have pari passu (i.e., equal and ratable) claims. In contrast, the doctrines of recharacterizing sales as transfers intended for security and collapsing LBO transactions are used to recharacterize or collapse contractual relationships between otherwise intact corporate structures. 
These doctrines thus can be loosely synthesized as judicial attempts to collapse or recharacterize corporate contractual arrangements that create externalities by shielding assets from third-party claims, triggered by material improprieties in the arrangement-especially (though not necessarily) where the arrangement being challenged shields assets of a party causing the improprieties. This synthesis, however, is both too broad and-because it cannot explain all cases-at the same time too narrow.

I therefore next use contract theory and economics to examine the core of this synthesis: challenging contractual arrangements in order to prevent externalities. Underlying this challenge is a problem that has long baffled contract theorists: the "major conceptual" problem of "[d]etermining which [externalities] are to count in constraining the ability of parties to contract with each other." ${ }^{68} \mathrm{I}$ attempt to solve this problem in the context of corporate contracting, and then use the solution to articulate a normative rule for collapsing or recharacterizing corporate structures. I then test and refine that rule by comparing it to the synthesis of positive-law doctrine. Finally, I show that the proposed rule, if adopted as a rule of law, would harmonize, clarify, and provide conceptual grounding to the jurisprudence of collapsing or recharacterizing corporate structures, including those discussed in Part II.

\section{ANALYSIS}

The possibility of challenging contractual arrangements in order to prevent externalities is an essential element of contract theory. ${ }^{69}$ As mentioned, though, the difficult question is when to allow such challenges.

\section{A. Contract Theory And Economics}

Contract law presumes that parties will not consensually enter into a contract unless each party perceives a net benefit. ${ }^{70}$ Courts therefore generally enforce contracts absent good reason not to do so. ${ }^{71}$ With so much banter about freedom of contract, ${ }^{72}$ however, it might seem surprising that there are any exceptions to

68. Michael J. Trebilcock, The Limits of Freedom of Contract 20 (1993). This Article argues the externalities that are to count for that purpose are those that (i) a contracting party knew or should have known would cause material harm to third parties, or (ii) cause harm that manifestly exceeds the aggregate benefit of the contracting. See infra notes 227-230 and accompanying text.

69. See infra notes $72-76$ and accompanying text.

70. TREBILCOCK, supra note 68 , at 7 .

71. Id.

72. See, e.g., John Weistart, et AL., The Contracts ExPerienCE § 1.F.7.A (DVD ROM 2003) (video colloquium with Girardeau Spann, Hon. Frank Easterbrook, Richard Epstein, Amy Chua, Katharine Bartlett, and H. Jefferson Powell presenting differing perspectives on the role of freedom of contract in American law); Stephen A. Siegel, Understanding the Nineteenth Century Contract Clause: The Role of the Property-Privilege Distinction and "Takings" Clause Jurisprudence, 60 S. CAL. L. Rev. 1 (1986) (discussing the sanctity of contracts as the norm of judicial thought in the 19th century); Mark Pettit, Jr., Freedom, Freedom of Contract, and The "Rise and Fall," 79 B.U. L. Rev. 263, 291-98 (1999) (discussing the tension between freedom of contract and public policy, and detailing the historical treatment of freedom of contract). 
contract enforcement. There are, though, three factors that make the presumption of contract enforceability rebuttable. ${ }^{73}$ The first is that the contract would thwart or significantly impair legislative policies. ${ }^{74}$ The second is that the contract harms one or more contracting parties. This is referred to as "paternalism." 75 The third is that the contract harms or otherwise infringes the rights of non-contracting parties. ${ }^{76}$ The infringement of non-contracting parties' rights is referred to as a negative externality, ${ }^{77}$ though for simplicity this Article uses the term externality.

In this Article's corporate context, paternalism should be insignificant. ${ }^{78}$ Legislative policies might be relevant, and will be considered as applicable. In that context, I do not question the merits of specific statutes but merely build my analysis on their foundations. ${ }^{79}$ Externalities, however, are most likely to arise because actions of the contracting parties may well affect, and possibly could harm, third parties.

But the mere existence of externalities should not necessarily defeat contract enforcement. Many contracts create externalities, yet they are enforced. When examining externalities, one must focus on which externalities should defeat contract enforcement, and under what circumstances. Certainly, a necessary, though insufficient, condition for defeating contract enforcement is that the externality must affect an identifiable person and cause material harm. ${ }^{80}$ This minimum

73. See generally Steven L. Schwarcz, Rethinking Freedom of Contract: A Bankruptcy Paradigm, 77 TEx. L. Rev. 515, 536-552 (1999) [hereinafter Schwarcz, Rethinking Freedom of Contract: A Bankruptcy Paradigm .

74. Although impairing legislative policies could be treated as an externality, discussed infra note 77 and accompanying text, I believe it is clearer to a reader to treat it separately.

75. See Anthony T. Kronman, Paternalism and the Law of Contracts, 92 YALE L.J. 763, 763-64 (1983) ("In general, any legal rule that prohibits an action on the ground that it would be contrary to the actor's own welfare is paternalistic.").

76. See Schwarcz, Rethinking Freedom of Contract: A Bankruptcy Paradigm, supra note 73, at 551.

77. See, e.g., Ian Ayres \& Robert Gertner, Filling Gaps in Incomplete Contracts: An Economic Theory of Default Rules, 99 YaLE L.J. 87, 88 (1989) (citing I. MACNEIL, CONTRACTS: EXCHANGE TRANSACTIONS AND Relations 346-47 (1978)); Kronman, supra note 75, at 763; Guido Calabresi \& A. Douglas Melamed, Property Rules, Liability Rules, and Inalienability: One View of the Cathedral, 85 HARV. L. REV. 1089, 1093 (1972); Cass R. Sunstein, Legal Interference with Private Preferences, 53 U. CH1. L. REv. 1129,1130 (1986) ("It may generally be agreed that if actions that gratify private preferences produce 'harm to others,' governmental intervention is appropriate."). The economic definition of externalities means "the indirect effect of a consumption activity or a production activity on the consumption set of a consumer, the utility function of a consumer or the production function of a producer." 2 THE New Palgrave: A Dictionary of ECONOmics 263 (John Eatwell et al. eds., 1987). Legal commentators, however, usually focus on externalities that harm or impose costs on third parties. See, e.g., TREBILCOCK, supra note 68, at 58; Frank H. Easterbrook \& Daniel R. Fischel, The Corporate Contract, 89 Colum. L. REv. 1416, 1436-41 (1989); Richard A. Epstein, Surrogacy: The Case for Full Contractual Enforcement, 81 VA. L. Rev. 2305, 2325-26 (1995); Richard A. Posner, Blackmail, Privacy, and Freedom of Contract, 141 U. PA. L. REV. 1817, 1818-19 (1993).

78. Cf. Schwarcz, Rethinking Freedom of Contract: A Bankruptcy Paradigm, supra note 73, at 546-51 (arguing that paternalism need not be taken into account when the contracting parties are sophisticated and represented by counsel).

79. Cf. Lucian Arye Bebchuk, A New Approach to Corporate Reorganizations, 101 HaRv. L. REv. 775, 776-77 (1988) (examining alternative approaches within bankruptcy reorganization without examining alternatives to bankruptcy reorganization).

80. See Schwarcz, Rethinking Freedom of Contract: A Bankruptcy Paradigm, supra note 73, at 55760 ; see also id. at $559 \mathrm{n} .249$ ("[T]he issue of materiality does not appear to be explicitly addressedmerely assumed-in most of the scholarly literature. For example, in commenting on Professor Jeffrey 
threshold reflects the value inherent in freedom of contracting. ${ }^{81}$ Satisfying this threshold does not guarantee a contract will be rejected due to the externality; it merely begins the inquiry.82

This Article starts from the assumption that externalities should be allowed to defeat contract enforcement only where that minimum threshold is met ${ }^{83}$ and the externalities cause the contracting in question to become economically inefficient. This reflects that the raison d'etre of contracting is efficiency. ${ }^{84}$ Society should want parties to contract in ways that are efficient, and therefore should enforce efficient contracts even though there may be externalities.$^{85}$ For example, a contract to build a major downtown construction project causes material harm: incessant noise, dust, and traffic impairment. Yet few would want to defeat this contract, which ultimately contributes numerous benefits and keeps the city vibrant. ${ }^{86}$ That begs the question, however, of what constitutes efficiency in the face of externalities.

The law and economics literature generally defines efficiency as meaning either Pareto or Kaldor-Hicks efficiency. ${ }^{87}$ Pareto efficiency means, in our context, that the contracting in question not only makes the parties to the contract better off but makes no other parties worse off. ${ }^{88}$ That standard, however, necessarily makes inefficient any contracting that creates uncompensated externalities. Because of this strictness, Pareto efficiency is an impractical standard for policy analysis: "[T]he conditions for Pareto superiority are almost never satisfied in the real

Gordon's argument that opting out of standard corporate charter provisions creates an externality because parties using the standard provision would have fewer precedents to rely on, Professor Lucian Bebchuk observed that 'the positive externalities created by standardization seem to be much larger with respect to the features of many technical products-such as VCRs or certain types of communication and computer systems--and still their magnitude does not appear sufficiently substantial to warrant mandatory intervention in these products' features.'") (quoting Lucian Arye Bebchuk, The Debate on Contractual Freedom in Corporate Law, 89 COLUM. L. REV. 1395, 1405 n.46 (1989)).

81. Schwarcz, Rethinking Freedom of Contract: A Bankruptcy Paradigm, supra note 73, at 557-60.

82. Id.

83. References hereinafter to externalities mean externalities that satisfy that minimum threshold.

84. See, e.g., A. Mitchell POLINSKY, AN INTROdUCtion to LAW AND ECONOMICs 29 (2003) (arguing that contract law is, effectively, "design[ed] ... according to the efficiency criterion"); ANTHONY T. KRONMAN \& RichaRd A. POSNER, THE ECONOMICS OF CONTRACT LAW 1-2 (1979) ("The fundamental economic principle with which we begin is that if voluntary exchanges are permitted ... resources will gravitate toward their most valuable uses .... The principle that voluntary exchange should be freely permitted in order to maximize value is frequently summarized in the concept (or slogan) of 'freedom of contract.'"); David W. Barnes \& Lynn A. Stout, Cases and Materials on LaW and ECONOMICS 180 (1992) (indicating that the efficiency rationale for contracting applies whether Pareto or Kaldor-Hicks is used as the efficiency standard).

85. Another way of thinking about this is that contracting could be inefficient if one or more of the Coase theorem assumptions are relaxed. One of those assumptions is that a firm contracts with everyone, and therefore fully internalizes the cost of its activities. But that assumption is incorrect to the contract creates uncompensated externalities; thus, one must examine the consequences of that incorrect assumption. Relaxing the Coase theorem does not show inefficiency; it merely invites a further inquiry.

86. These externalities, however, might be inequitably borne by third parties, such as those living or working close to the construction site. In certain circumstances, the law attempts to internalize these extemalities by making the contracting parties liable for the harm they cause. See infra Part Ill.C.

87. See infra notes 88-102 and accompanying text.

88. See Jules L. Coleman, Efficiency, Utility, and Wealth Maximization, 8 HofSTRA L. Rev. 509 (1980); Thomas J. Miceli \& Kathleen Segerson, Defining Efficient Care: The Role of Income Distribution, $24 \mathrm{~J}$. LEGAL STUD. 189, 192 (1995). 
world." 89 Thus, "it is pretty clear that the operating definition of efficiency in economics is not Pareto superiority." 90 Nor is it a practical standard for analyzing actual corporate structures: Most such structures create externalities that cannot, pragmatically, be completely internalized. ${ }^{91}$

Economists generally accept Kaldor-Hicks as the operating standard of efficiency: "When an economist says that [something] is efficient, nine times out of ten he means Kaldor-Hicks efficient."92 Likewise, when an economist says that contracting is efficient, he or she usually is thinking of Kaldor-Hicks efficiency ${ }^{93}$ Kaldor-Hicks efficiency means that the aggregate benefit exceeds the aggregate harm, including externalities. ${ }^{94} \mathrm{~A}$ transaction can be Kaldor-Hicks efficient even if the "winners" (the contracting parties and any third parties who are benefited) do not compensate the "losers" (e.g., third-parties harmed by externalities).$^{95}$ This standard of efficiency attempts to balance overall societal benefit and harm.

Although the appropriate standard for policy analysis, ${ }^{96}$ Kaldor-Hicks efficiency alone may be insufficient for analyzing privately-contracted corporate structures, where policy considerations can be less important than actual consequences. Because Kaldor-Hicks takes externalities into account only by including them in the balance of aggregate harm and aggregate benefit, a corporate structure can be Kaldor-Hicks efficient even though its externalities are not internalized by the

89. Richard A. POSNER, ECONOMIC ANALYSIS OF LAW $\S 1.2$, at 14 (4th ed. 1992) (hereinafter PosNER, ECONOMIC ANALYSIS OF LaW (4th ed.)].

90. Id. Accord Louis Kaplow \& Steven Shavell, Faimess Versus Welfare, 114 HaRv. L. REv. 961 , 1015 (2001) (arguing it is infrequent that a policy is under consideration that will make all parties better off, and therefore a Pareto-efficiency standard is usually unhelpful for policy determinations); cf. Anthony T. Kronman, Contract Law and Distributive Justice, 89 YALE L.J. 472, 487 (1980) ("IU]nlike a court, a legislature must evaluate the effects of proposed rules on classes of persons rather than on particular, identifiable individuals.").

91. See Richard A. POSNER, ECONOMIC ANAlysis of LAW 13 (6th ed. 2003) [hereinafter POSNER, ECONOMIC ANALYSIS OF Law (6th ed.)] (observing that "most transactions (and if not a single transaction, then a series of like transactions) have effects on third parties, if only by changing the prices of other goods .... The conditions for Pareto superiority [thus] are almost never satisfied in the real world.").

92. POSNER, ECONOMIC ANALYSIS OF LAW (4th ed.), supra note $89, \S 1.2$, at 14 .

93. See, e.g., POSNER, ECONOMIC ANALYSIS OF LAw (6th ed.), supra note 91 , at 13 (using the KaldorHicks model in discussing the efficiency of contract law: "if $A$ values [a] wood carving at $\$ 50$ and $B$ at $\$ 120$, so that at any [negotiated contract] price between $\$ 50$ and $\$ 120$ the transaction creates a total benefit of $\$ 70$ (at a price of $\$ 100$, for example, A considers himself $\$ 50$ better off and B considers himself $\$ 20$ better off), it is an efficient transaction, provided that the harm (if any) done to third parties (minus any benefit to them) does not exceed \$70."); see also Blake D. Morant, Contracts Limiting Liability: A Paradox With Tacit Solutions, 69 TuL. L. REv. 715, 767-70 (1995) (arguing that KaldorHicks is the "more practical method of evaluating efficiency" of voluntary contracts, such as indemnity agreements). In some cases, however, commentators simplify the analysis in order to avoid having to distinguish between Pareto and Kaldor-Hicks efficiency. See, e.g., KRONMAN \& POSNER, THE ECONOMics OF CONTRACT LAW, supra note 84 , at 2 n.l ("Many contracts have third-party effects .... We shall therefore ignore them."); POLINSKY, supra note 84, at $29 \mathrm{n} .16$ (presuming "that no one else is affected by the contract").

94. POSNER, ECONOMIC ANALYSIS OF LAW, supra note 89, $\$ 1.2$, at 13-14.

95. Id. $\S 1.2$, at 14 .

96. Kaplow \& Shavell, supra note 90, at 1015 (arguing for the Kaldor-Hicks standard because virtually any governmental policy will benefit some members of the public and hurt others, making it impractical for government to compensate all those who are hurt; the most government could hope for is that its policies provide a net positive benefit). 
contracting parties. The failure to internalize externalities, however, has important distributional consequences, ${ }^{97}$ and even the perception of distributional inequities can discourage market participants by undermining expectations. ${ }^{98}$ It may, for example, discourage financiers or suppliers of goods and services from extending credit to firms, thereby jeopardizing the underlying economic viability of the corporate structure. More generally, this dichotomy between efficiency and distributional consequences is fundamental not only to scholarly debates but also to public perceptions. ${ }^{99}$

To attempt to resolve this dichotomy, at least in the context of collapsing corporate structures, this Article employs a two-step analysis. ${ }^{100}$ The first step contemplates that inefficient corporate structures-using the Kaldor-Hicks test of efficiency-may be collapsed. This step takes externalities into account through an aggregate balancing of benefit and harm. The second step examines the extent to which, notwithstanding Kaldor-Hicks efficiency, externalities should be internalized. ${ }^{101}$ That step weighs the practicalities of internalizing externalities caused by corporate structures and the extent to which the law should respect corporate structures that create non-internalized externalities.

The two-step analysis shows that allowing Kaldor-Hicks efficient freely-negotiated corporate structures that internalize intentional externalities is the socially optimal result, even though the failure to internalize unintentional externalities may dis-

97. Cf. POSNER, ECONOMIC ANALYSIS OF LAW (6th ed), supra note 91, at 25 (observing that KaldorHicks efficiency is not intended to ensure equitable treatment because "justice and fairness [are] not economic terms"). Concern about distributional consequences led me to analyze externalities in the securitization context. See Schwarcz, Securitization Post-Enron, supra note 40, at 1551-68 (arguing that securitization transactions, in the aggregate, create net value for non-adjusting creditors; and even though non-adjusting creditors sometimes will be harmed where an originator that goes bankrupt overinvests the securitization proceeds, that harm should be more than offset in the aggregate by the lower interest-cost burden on originators and the liquidity provided to originators that are unable to borrow).

98. See, e.g., Schwarcz, A Fundamental Inquiry Into the Statutory Rulemaking Process of Private Legislatures, supra note 5, at 933 ("Fairness encompasses the oft-heard goal of commercial law-preserving expectations."); Richard Danzig, A Comment on the Jurisprudence of the Uniform Commercial Code, 27 STAN. L. Rev. 621, 622-23 (1975) ("Commercial law ... deals with a subcommunity ... whose primary rules derive from a sense of fairness widespread-if imprecisely defined-within the commercial community.").

99. See, e.g., Paul Craig Roberts, Who Did More for Mankind, Mother Teresa or Mike Milken?, Bus. WK., Mar. 2, 1998, at 28 (observing that "Milken created wealth, jobs, incomes, and new products for large numbers of people, while Mother Teresa redistributed wealth donated by philanthropists.").

100. My two-step approach is indirectly inspired by the work of Professors Korobkin and Ulen. See Russell B. Korobkin \& Thomas S. Ulen, Efficiency and Equity: What Can Be Gained by Combining Coase and Rawls?, 73 WASH. L. Rev. 329, 342 (1998) (responding to the criticism that economic analysis of law fails to address distributive justice concerns by arguing, according to the Second Theorem of Welfare Economics, that "issues of equity and efficiency are separable. That is, different social policies can independently achieve social goals of equity and efficiency. Society need not seek to achieve both goals simultaneously through a single policy.").

101. Where contracting parties fail to internalize externalities, government theoretically can mitigate distributional inequities through taxation and transfers. For example, government could give tort claimants, the most common type of non-adjusting creditor, priority over other unsecured creditors; or it could create a fund for paying unpaid tort claims; or it could give tax breaks to unpaid tort claimants. Governmental actions of this sort do not, however, appear politically likely at this time. This Article therefore focuses on the extent to which contracting parties should internalize their externalities. 
courage some market participants at the margin. ${ }^{102}$ It therefore resolves the dilemma that using Kaldor-Hicks efficiency alone is inadequate, whereas using a Pareto efficiency standard would render any corporate structure with non-internalized externalities_effectively most corporate structures_inefficient.

\section{B. Formulating a Rule}

The first step of this Article's two-step analysis is to articulate a preliminary rule for collapsing corporate structures based on the aforesaid factors that make the presumption of contract enforceability rebuttable, taking externalities into account only in the aggregate balancing of benefit and harm-according to the Kaldor-Hicks model. This yields the following rule: a corporate structure ${ }^{103}$ should be respected unless $(\mathrm{x})$ it thwarts or significantly impairs legislative policies, or (y) taking into account externalities, the aggregate harm caused by the structure exceeds the structure's aggregate benefit (hereinafter "net harm"). ${ }^{104}$

Comparing this rule to the synthesis of positive-law doctrine on collapsing corporate structures ${ }^{105}$ reveals the rule lacks a triggering event for its application. Positive law, in contrast, sometimes requires a triggering event: a finding of material improprieties in the corporate arrangement. ${ }^{106}$ This raises the normative question of whether the rule should require a triggering event.

A triggering event, such as a finding of material improprieties, is not necessarily inconsistent with the preliminary rule, ${ }^{107}$ and there are at least three cogent reasons for requiring it. First, the existence of material improprieties provides a signal to market participants that the structure could be collapsed, ${ }^{108}$ thereby helping to establish the expectations that are essential to corporate and commercial transactions and minimizing the likelihood that innocent third parties who relied on

102. Cf. Kimberly D. Krawiec, Fairness, Efficiency, and Insider Trading: Deconstructing the Coin of the Realm in the Information Age, $95 \mathrm{Nw}$. U. L. RFv. 443, 499-500 (2001) (arguing that proscribing a form of intentional, but not unintentional, insider trading is the socially optimal result).

103. As used in this rule, the term "corporate structure" includes legal relationships among firms. See supra note 67 and accompanying text.

104. Cf. text accompanying note 92 , supra (explaining that Kaldor-Hicks efficiency means that the aggregate benefit exceeds the aggregate harm, including externalities).

105. That synthesis is articulated in the first sentence of the paragraph accompanying note 69 .

106. As discussed, this triggering event is especially robust where the corporate arrangement in question shields assets of a party causing the improprieties. See supra Part II.E.

107. The preliminary rule is only intended to posit which externalities should be allowed to defeat the presumption of contract enforcement and not intended to prevent courts from looking to other factors when deciding whether or not to enforce the contract. See supra notes 73-77 and accompanying text (observing that externalities only make the presumption of contract enforceability rebuttable).

108. The extent to which material improprieties provide an actual signal to market participants that the structure could be collapsed will, of course, vary. It is likely to be strongest in the veil-piercing and collapsing-LBO contexts, the former often involving improprieties that amount to blatant wrongdoing, the latter involving the types of improprieties (like funding an insolvent LBO) that should be obvious. The signaling is likely to be weakest in the context of recharacterizing sales as transfers intended for security because it sometimes can be difficult to ascertain whether a given agreement creates a sale of financial assets or merely a transfer of such assets intended for security. Cf. U.C.C. $\S 9-109$ (a)(3) \& cmt. 4 (2004) (including sales of certain types of financial assets under Article 9 of the U.C.C. in order to "avoidll difficult problems of distinguishing between transactions in which a receivable secures an obligation and those in which the receivable has been sold outright." ). 
the limited-liability rule of corporation law would be harmed by the structure's collapse. ${ }^{109}$ Second, such a triggering event helps ensure the integrity of the limited-liability rule, because "[t]o decide that there are any circumstances in which shareholders can be held liable for tort damages even though the formalities of the corporate form have been observed is to discard limited liability in principle." 110 Third, and most important, the triggering event helps manage litigation costs by avoiding having to determine whether there is a Kaldor-Hicks imbalance merely because a lawsuit is filed. These factors, I believe, outweigh any risk that a triggering event will deprive injured creditors of a remedy where a formalistically proper corporate structure causes net harm. ${ }^{111}$

I therefore propose requiring, as a triggering event, a finding of material improprieties in the corporate structure before applying at least the Kaldor-Hicks balancing part of the rule. As so modified, the rule can be restated as follows: a corporate structure should be respected unless it $(\mathrm{x})$ thwarts or significantly impairs legislative policies, or $(\mathrm{y})$ has material improprieties and causes net harm. ${ }^{112}$

It is unnecessary, and even potentially limiting, for the rule to attempt to precisely define what constitutes material improprieties. Courts should define that, because material improprieties are more easily recognized than defined. ${ }^{113} \mathrm{Ex}$ amples of material improprieties that courts have recognized in the past include substantial breakdowns of corporate formalities, such as difficulty in segregating and ascertaining a firm's individual assets and liabilities ${ }^{114}$ or making significant transfers of assets without formal observance of corporate formalities; ${ }^{115}$ inadequate capitalization or transactions that render a firm insolvent; ${ }^{116}$ domination of a firm by its parent to the extent that the firm's corporate independence is lacking and the firm and its parent are effectively alter egos; ${ }^{117}$ and transactions where the economic substance belies the corporate form. ${ }^{118}$

109. Vallejo v. Wheeler, 98 Eng. Rep. 1012, 1017 (K.B. 1774) (Mansfield, L.J.) (declaring that "[i]n all mercantile transactions the great object should be certainty"); see also Schwarcz, A Fundamental Inquiry Into the Statutory Rulemaking Process of Private Legislatures, supra note 5, at 928-31 (same) These expectations would include, for example, those of parties who extend credit in good faith to the parent-firm in a parent-subsidiary structure relying on the limited-liability rule of corporation law. See infra notes 231-236 (discussing the limited-liability rule).

110. See Hansmann \& Kraakman, Toward Unlimited Shareholder Liability for Corporate Torts, supra note 19 , at 1932 (emphasis removed).

111. This risk is not as high as it might appear because collapsing a corporate structure does not ensure that creditors will be made whole; the contracting parties may have become judgment proof.

112. Note that the existence of material improprieties does not, per se, trigger collapse or recharacterization but merely invites further inquiry as to whether collapse or recharacterization is appropriate.

113. This approach follows the judicial litmus test of "I know it when I see it." Jacobellis v. Ohio, 378 U.S. 184, 197 (1964) (Stewart, J., concurring). The Supreme Court adopted such a test for adjudicating pornography cases. See Miller v. California, 413 U.S. 15, 24 (1973) ("whether 'the average person, applying contemporary community standards' would find that the work, taken as a whole, appeals to the prurient interest"); Roth v. United States, 354 U.S. 476, 489 (1957).

114. In re Vecco Constr. Indus., Inc., 4 B.R. 407, 410 (Bankr. E.D. Va. 1980).

115. Id.

116. Franklin A. Gevurtz, Corporation LaW 70 (2000); see also supra note 54 and accompanying text.

117. See supra note 20 and accompanying text.

118. See supra note 41 and accompanying text. 


\section{Internalizing Externalities}

The foregoing analysis constitutes only the first step in this Article's two-step analysis of determining when to collapse corporate structures. The second step is to examine the extent to which, notwithstanding Kaldor-Hicks efficiency, a corporate structure should be collapsed in order to internalize externalities.

As discussed, Kaldor-Hicks efficiency takes externalities into account only as part of an aggregate calculation. Because the winners (the contracting parties) need not compensate the losers (non-adjusting creditors) under that standard, a corporate structure can be Kaldor-Hicks efficient even though it causes externalities that harm those creditors. ${ }^{119}$ To mitigate distributional inequities, ${ }^{120}$ the law sometimes looks beyond Kaldor-Hicks efficiency and tries to internalize externalities. ${ }^{121}$ This section (Part III.C) examines whether and to what extent the law should look beyond Kaldor-Hicks efficiency to try to internalize externalities caused by corporate structures. ${ }^{122}$

This is a practical inquiry: There is little question that externalities should be internalized, ${ }^{123}$ but any regulatory measure for accomplishing that should not be

119. See supra note 95 and accompanying text.

120. The discussion in this Part III.C focuses on distributional consequences, as opposed to such non-distributional notions of fairness as corrective justice, sanctity of promises, or retributive justice. See Louis Kaplow \& Steven Shavell, The Conflict Between Notions of Faimess and the Pareto Principle, 1 AM. L. \& ECON. REV. 63, 64-65 (1999) (referring to these and other theories of faimess that are "based, at least in part, on factors unrelated to individuals' well-being.").

121. See, e.g., Oliver Wendell Holmes, The COMmon LaW (1881), Lecture I (arguing that tort law had evolved from a standard based on morality to one based on external harm); WILLIAM L. Prosser \& W. Page Keeton, The Law of TORTs 22 (5th ed. 1984) (observing that " $[\mathrm{t}]$ he twentieth century has seen the development of entire fields of liability in which the defendants are held liable for well-intentioned and entirely reasonable conduct, because it is considered to be good social policy that their enterprises should pay their way by bearing the loss they inflict.").

122. This Part III.C does not, therefore, purport to address any distributional inequity that exists immediately prior to creation of a corporate structure; it solely addresses distributional inequities caused by the structure.

123. Although the proposition that externalities should be internalized seems axiomatic, some might find it useful to articulate the proposition from the standpoint of the Coase theorem, which states, in basic terms, that under restrictive assumptions including costless bargaining, well-defined property and liability rules, full information, and no other transaction costs, bargaining between market players will produce the most socially efficient outcomes regardless of the initial wealth allocation of the players. Coase's conception of efficiency is Pareto efficiency, as at least one person is made better off, while the rest of society is not made worse. This type of Pareto efficiency is made possible by Coase's smooth pricing system in which each player fully internalizes the costs of a bargain through price changes in all other contractual relationships into which it has entered. R.H. Coase, The Problem of Social Cost, 3 J.L. \& ECON. 1 (1960). Thus, under those restrictive assumptions, parties adversely affected by externalities will bargain with the source of the externalities to arrive at a socially optimal result by internalizing the externalities. See id. at 10. Coase makes this point in an example about a cattle herder and farmer with conflicting land use needs: "I think it is clear that if the cattleraiser is liable for damage caused and the pricing system works smoothly, the reduction in the value of production elsewhere will be taken into account in computing the additional cost involved in increasing the size of the herd." Id. at 5. Given such internalization, any Kaldor-Hicks improvement will translate into a Pareto improvement. Id. at 2. In the case of corporate structures, however, the Coase theorem assumption of costless bargaining is violated because non-adjusting creditors cannot bargain. For example, tort creditors obtain their claims involuntarily and have no bargaining power to better their claims. See Bebchuk \& Fried, supra note 55, at 869. Thus, one cannot rely on the theorem's prediction that a Kaldor-Hicks improvement will translate a Pareto improvement, and must 
so costly as to undermine the basic Kaldor-Hicks efficiency. I therefore continue the inquiry by examining the costs of internalizing externalities caused by corporate structures. Analytically, it is useful to split this inquiry into two parts: intentional externalities, and unintentional externalities. Consider first intentional externalities, where the contracting parties enter into a corporate structure intended to harm creditors.

Regulatory measures for internalizing intentional externalities should be feasible. ${ }^{124}$ Intentional harm would be expected to occur in relatively few cases, and in those cases the existence of intent will often be evident from the facts. ${ }^{125}$ Moreover, a Kaldor-Hicks standard alone may seem so patently inequitable as to make market participants uncomfortable. ${ }^{126}$ Perhaps implicitly for these reasons, the law often requires intentional externalities to be internalized. For example, under both federal bankruptcy ${ }^{127}$ and state fraudulent transfer law, ${ }^{128}$ virtually any transfer of property or incurrence of an obligation made or incurred "with actual intent to hinder, delay, or defraud" creditors can be invalidated. ${ }^{129}$

For these same reasons, the preliminary rule should similarly aim to internalize intentional externalities. That could be accomplished by restating the rule as follows: a corporate structure should be respected unless it $(x)$ thwarts or significantly impairs legislative policies, or (y) has material improprieties and causes either net harm or intentional externalities.

That restated rule, though, still does not address harm caused by unintentional externalities. Even where the contracting parties do not intend to harm creditors, it is possible that creditors inadvertently could be harmed. ${ }^{130}$ There are two possible ${ }^{131}$ ways this harm could be redressed: by governmental scrutiny of corporate

make further inquiry. Cf. Robert E. Scott, The Truth About Secured Financing, 82 CoRNELL L. REv. 1436, 1443 (1997) ("Systematic nonadjustment raises a number of interrelated questions. What are the efficiency effects of nonadjustment on debtors' financing choices? What are the distributional consequences of nonadjustment?"). The important question, which I address in the text above, is what should be the nature of that inquiry.

124. These regulatory measures could include collapsing the relevant corporate structure or making the contracting parties liable for the harm they cause. See infra note 132 and accompanying text.

125. See infra notes 169-179 and accompanying text (examining how to prove intent to harm creditors).

126. Cf. POSNER, ECONOMIC ANALYSIS OF LAW (6th ed.), supra note 91, at 264-65 (arguing that there is economic value in adhering to generally accepted moral principles); Krawiec, supra note 102 , at 470-71 (recognizing the commonly held presumption that "if investors believe that the stock market is systematically unfair and accords advantages to insiders and others with superior access to material nonpublic information, then the investors may exit the market.").

127. 11 U.S.C. $\$ 548$ (2000) ("Fraudulent transfers and obligations").

128. The fraudulent transfer law of most states is based on the Uniform Fraudulent Transfer Act, which parallels the provisions of the Federal Bankruptcy Code's fraudulent transfer law but applies outside of a federal bankruptcy case and has a four-year, rather than one-year, statute of limitations. Lawrence P. King \& Michael L. Cook, Creditors' Rights, Debtors' Protection and Bankruptcy $\S \S 6.01-.05$ (3d ed. 1997).

129. 11 U.S.C. $\$ 548(a)(1)(A)$. Although the quoted language above is from 11 U.S.C. $\S 548(a)(1)(A)$, state fraudulent transfer law contains similar language. See, e.g., UNIF. FraUdulENT TRANSFER ACT $\S 4(a)(1)(2003)$.

130. See, e.g., Bebchuk \& Fried, supra note 55, at 869-70 (originally raising this concern in the context of examining the efficiency and distributional consequences of secured lending).

131. I have previously noted that although government could also mitigate distributional inequities through taxation and transfers, those solutions are not politically viable. See supra note 101 . 
structures in order to restrict or prohibit harmful structures, or by making the contracting parties liable for the externalities they unintentionally cause (thereby internalizing the harm). ${ }^{132}$

Government scrutiny of unintentional externalities does not appear feasible. It would require a regulatory framework that not only would be very costly ${ }^{133}$ but also, at least in the United States, inconsistent with fundamental notions of contract and corporation law. ${ }^{134}$ This lack of feasibility is illustrated by the fact that, even though the limited-liability rule of corporation law may generate externalities, government does not "take a more active role in assuring the solvency of corporations," as it does with banks and under European corporation law ${ }^{135}$ That would require "continuous regulatory scrutiny of the corporation by an administrative agency, a statist solution that has thus far been resisted in most nonfinancial industries in the United States. "136 Furthermore, the remedy imposed by governmental scrutiny could backfire. If, for example, such scrutiny revealed a corporate structure that, notwithstanding scrutiny, has been in use, any attempt by government to collapse or recharacterize the structure could harm creditors of the more solvent firm in that structure. ${ }^{137}$

Making the contracting parties liable for unintentional externalities would also be costly. Imposing liability, even strict liability, would have minimal deterrent value - and thus would not discourage creation of externalities ${ }^{138}$ - precisely because the externalities are unintentional. ${ }^{139}$ Even worse, the imposition of liability could give rise to enormous litigation costs. ${ }^{140}$ To understand why, consider the possible standards of liability. A strict liability standard would clearly invite a multitude of lawsuits by creditors. ${ }^{141}$ Any more-nuanced standard of liability, how-

132. POSNER, ECONOMIC ANALYSIS OF LAW (6th ed.), supra note 91, at 383 (discussing the "two methods of public control - the common law system of privately enforced rights and the administrative system of direct public control"). Although the analysis in the text is based primarily on practical considerations, it should be noted that a liability regime-i.e., making the contracting parties liable for the externalities they unintentionally cause-seems more justified on theoretical grounds. Contracting is judged by efficiency standards, so the enforceability of a contract should be similarly judged. This does not mean that contracting parties should not be subject to some other rule-such as liability for harm caused by the contract's externalities-in order to mitigate such harm. This combination of policies gives the benefit of the doubt to freedom of contract, encouraging parties to enter into contracts if they believe their resulting benefits will exceed any liability. $C f$. supra note 100 (explaining that issues of equity and efficiency are separable).

133. POSNER, ECONOMIC ANAlysis OF LAW (6th ed.), supra note 91, at 385

134. Id. at $413-14$.

135. Id.

136. Id. at 414.

137. See infra note 187 and accompanying text.

138. Indeed, to the limited extent it constitutes a deterrent, a strict liability standard could be a double-edged sword, discouraging even some beneficial corporate structures.

139. The analysis above only need address unintentional externalities. Intentional externalities are already covered by this Article's proposed rule. See supra notes 127-129 and accompanying text.

140. Besides litigation costs, there may be insurance costs to mitigate risk and higher transaction costs for all parties who have to allocate this extra risk. These extra costs, which create a small benefit for a discrete few, ultimately fall on shareholders, consumers and taxpayers.

141. POSNER, ECONOMIC ANALYSIS Of LAW (6th ed.), supra note 9l, at 191 (noting the expense of imposing a strict liability standard for externalities) 
ever, would have no more deterrent value than strict liability but potentially higher administrative costs.

For example, a standard such as negligence or gross negligence would be less likely than strict liability to deter the contracting parties from unintentionally causing externalities. These standards could have higher costs, however, because of the difficulty ascertaining, in any given case, whether the contracting parties breached the applicable standard. ${ }^{142}$ What, for example, would constitute negligence or gross negligence in creating a corporate structure? Would a solvent firm be negligent or grossly negligent if it enters into a structure limiting the amount of assets against which potential future creditors could claim? Related questions regarding adequacy of a firm's capital to engage in its business sometimes arise under bankruptcy fraudulent conveyance law, ${ }^{143}$ but courts have never been able to define with any precision what adequate capital means. ${ }^{144}$

Making the contracting parties liable for unintentional externalities is therefore costly and would have minimal deterrent value. Collapsing corporate structures that give rise to such externalities would have no greater deterrent value and would be even more costly, entailing at least the same litigation costs but increasing costs by harming creditors of the more solvent firm in the structure. ${ }^{145}$

This does not necessarily mean the costs would undermine Kaldor-Hicks efficiency, but it is unrealistic to expect courts to make that determination. The resolution is complex because internalizing externalities would reduce harm to creditors but, at the same time, reduce benefits to the contracting parties who did not intend the harm. Moreover, any reduced harm to creditors would have to be offset by benefits that the relevant corporate structure provides to other creditors. ${ }^{146}$ To be practical, there needs to be some sort of rough benchmark. The law

142. Cf. POSNER, ECONOMiC ANALYSis of LAw (4th ed.), supra note 89, at 260 ("IS]trict liability involves certain costs that negligence liability does not"). It is difficult to predict with certainty, however, whether overall costs would be higher because a more-nuanced liability standard, particularly one of gross negligence, might discourage some litigation.

143. See 11 U.S.C. $\$ 548(a)(1)(B)($ ii)(II) (2000).

144. The debate over what adequate capital means "has engendered confusion over the relationship between [the] concepts [of insolvency and inadequate capital]: some courts have equated a finding of equitable insolvency with that of unreasonably small capital, whereas others have said that unreasonably small capital encompasses financial difficulties short of equitable insolvency." Compare Moody v. Sec. Pac. Bus. Credit, Inc., 971 F.2d 1056, 1070 (3d Cir. 1992) (comparing United States v. Gleneagles Inv. Co., 565 F. Supp. 556, 580 (M.D.P.A. 1983) ("[A] finding of insolvency is ipso facto a finding that the debtor was left with unreasonably small capital after the conveyance.") with Murphy v. Meritor Sav. Bank (In re O'Day Corp.), 126 B.R. 370, 407 (Bankr. D. Mass. 1991) ("It must be remembered that ' $[\mathrm{u}$ ]nreasonably small capitalization need not be so extreme a condition of financial debility as to constitute equitable insolvency .... .")); see also Barrett v. Cont'l Ill. Nat'l Bank and Trust Co., 882 F.2d 1, 4 (lst Cir. 1989) (disagreeing with the Gleneagles Inv. Co. court, and requiring "a court to examine a company's capital throughout a reasonable period of time surrounding the precise date of a challenged transfer" rather than at the time of the transaction); COLLIER ON BANKRUPTCY, supra note 32 , I 548.05[3] (outlining the circuit split regarding the proper factors and the correct test courts should use to determine whether a firm has "unreasonably small capital").

145. This additional harm could be mitigated by including it in the decision-making balance, but that complication would increase the litigation cost even further. See infra note 187.

146. Recall that some firms in a corporate structure will necessarily be more solvent than other firms, and thus collapsing the structure would benefit creditors of the less solvent firm(s) but harm creditors of the more solvent firm(s). See supra note 35 and infra note 187 and accompanying text (discussing offsetting costs and benefits in the substantive-consolidation context). 
traditionally supplies a benchmark: It does not normally attempt to internalize externalities where the internalization would involve high costs. ${ }^{147}$

Because any attempt to collapse corporate structures causing unintentional externalities would involve high costs, this benchmark suggests that the law should not attempt to collapse those structures. This is a sensible result: Absent intent to harm, the actual harm to creditors is likely to be small, ${ }^{148}$ whereas collapsing those structures could generate costs that often exceed the harm being redressed. ${ }^{149}$

I therefore conclude that the law should not attempt to collapse corporate structures causing only unintentional externalities. This is a normative conclusion, but it is supported by the evolution of positive law intended to internalize externalities. ${ }^{150}$ Nuisance law, the quintessential body of law entitling persons harmed by externalities to seek compensation from those causing the externalities, evolved from a standard of strict liability to an intentional tort. ${ }^{151}$ This shift occurred when the nuisance doctrine expanded from strictly physical invasions of noxious substances, such as sewage unintentionally spilling from a privy to the cellar of a neighbor's house, to less tangible invasions such as noise of low-flying airplane and blocking sunlight. ${ }^{152}$ There needed to be a tightening of the liability standard, lest it result in a flood of litigation. Requiring intentionality provided that tightening. ${ }^{153}$ Similarly, unintentional harm caused by the creation of corporate structures is not physical. Rather, like airplane noise or blocking sunlight, it is intangible and indirect. Therefore, as with nuisance law, restricting liability to intentional harm would help prevent a flood of litigation.

For these reasons, this Article's proposed rule should not require unintentional externalities to be internalized, though it should aim to internalize intentional externalities. Thus, a corporate structure should be respected, and the contracting parties should not be liable, unless the structure (x) thwarts or significantly im-

147. POSNER, ECONOMIC ANALYSIS OF LAW (6th ed.), supra note 91, at 191 (observing that litigation costs may explain why the common law does not compensate people for rendering external benefits"a right of restitution creates a legal claim whenever a benefit is conferred; and the costs of processing the claims can be horrendous"); PROSSER \& KEETON, supra note 121, at 23 (observing that "[i]t does not lie within the power of any judicial system to remedy all human wrongs. The obvious limitations upon the time of the courts, the difficulty in many cases of ascertaining the real facts or of providing any effective remedy, have meant that there must be some selection . . . . The courts always have stood more or less in dread of a 'flood of litigation' involving problems which they are not prepared to deal with.").

148. Cf. Robert E. Scott, The Truth About Secured Financing, 82 CORNELL L. Rev. 1436, 1443 (1997) (suggesting that only systematic harm to non-adjusting creditors should be problematic).

149. Cf. Morant, supra note 93 , at 770 ("in many instances, compensating all losers will be complicated and expensive and, therefore, not efficient.")

150. I am not suggesting in this paragraph that positive law outcomes should support normative law conclusions, but merely that the logic underlying the evolution of nuisance law is consistent with my normative law conclusion.

151. PROSSER \& KEETON, supra note 121 , at $624-25$.

152. Id.

153. Id. at $625-26$. Another possible reason the liability standard of nuisance law has tightened is that other theories of liability have evolved to protect interests in the use and enjoyment of property. Cf. id. at 624 . 
pairs legislative policies, or (y) has material improprieties and causes either net harm or intentional externalities. ${ }^{154}$

I next test the proposed rule (hereinafter, the "Rule") by applying it to the jurisprudence of collapsing or recharacterizing the corporate structures discussed in Part II. These applications show that the Rule would harmonize and provide conceptual clarity to that jurisprudence. The applications also shed light on how the Rule should be refined to maximize its utility.

\section{Applications}

\section{Piercing the Corporate Veil}

I start by applying the Rule to the doctrine of piercing the corporate veil. If the Rule were adopted as a rule of law, there would be two inquiries: first, whether the relevant corporate structure thwarts or significantly impairs legislative policies; second, whether the structure has material improprieties and, if so, whether it would cause either net harm or intentional externalities. If either inquiry is answered in the affirmative, the corporate structure should not be respected.

The type of parent-subsidiary corporate structures at issue in the veil-piercing context would not appear to thwart or significantly impair any legislative policies. The relevant policies are those of corporation law, which regards limited liability as fundamental: Shareholders are generally not liable for the debts of their corporations. ${ }^{155}$ Even undercapitalizing a subsidiary does not violate corporate-law policy so long as the subsidiary's capital meets the often artificially low minimum requirements of the relevant corporation law. ${ }^{156}$ This first inquiry therefore must be answered in the negative. ${ }^{157}$

Regarding the second inquiry-whether the relevant corporate structure has material improprieties and, if so, whether the structure would cause either net harm or intentional externalities-the existence of improprieties is indeed the most common justification for invoking the veil-piercing doctrine. Some even argue, as does this Article, that veil piercing is only appropriate where there are such improprieties. ${ }^{158}$ The second inquiry is thus answered in the affirmative to

154. A reader disagreeing with this proposed rule, however, could consider reformulating it, perhaps as follows, to also take into account unintentional externalities: a corporate structure should be respected unless it $(x)$ thwarts or significantly impairs legislative policies, or $(y)$ has material improprieties and harms creditors.

155. See Stephen B. Presser, Piercing the Corporate Veil. $\S 1: 1$ (2004); Cox, supra note 19 , $\S 7.7$, at 7.11 ("No principle is more engrained in corporate law than that shareholders enjoy limited liability"). Although I recognize that some scholars normatively question the doctrine of limited liability (see infra notes 231-236 and accompanying text), the analysis above only needs to address actual legislative policies.

156. GEVURTZ, supra note $116, \$ 2.1 .2 \mathrm{a}$, at 125,129 . Undercapitalization may well thwart the policies of bankrupicy law, but that is separately addressed by the bankruptcy doctrine of substantive consolidation. See infra Part III.D.2.

157. Nonetheless, perceived violations of the legislative policy behind limited corporate liability might account for at least some of the subjectivity and inconsistent application of the veil-piercing doctrine. See infra note 166 and accompanying text.

158. See Olthoff, supra note 20, at 312 and PrESSER, supra note 155, $\$ 1: 8-9$ (citing Robert Clark, The Duties of the Corporate Debtor to its Creditors, 90 HARV. L. REV. 505 (1977)). 
the extent there are material improprieties, such as difficulty in segregating and ascertaining a firm's individual assets and liabilities, significant transfers of assets without formal observance of corporate formalities, inadequate capitalization, or domination of a firm by its parent that effectively makes the firm an alter ego. ${ }^{159}$

That answer does not, however, end the analysis. In order to collapse the corporate structure, there also must be a finding of either net harm or intentional externalities. Consider first net harm. Because the contracting parties expect to benefit from securitization, ${ }^{160}$ creditors are the only parties who would suffer any harm (the harm being that the corporate structure shields assets from their claims). ${ }^{161}$ Piercing the corporate veil thus should be justified where, absent that remedy, there is net harm-meaning that the aggregate harm to creditors exceeds the aggregate benefit of preserving the structure. ${ }^{162}$

Courts, however, rarely if ever engage in this type of balancing test when applying the veil-piercing doctrine. Instead, after finding evidence of improprieties, ${ }^{163}$ judges decide whether to pierce the corporate veil based on their own personal notions of fairness and equity; ${ }^{164}$ and in some cases, the greater the improprieties, the more likely are courts to collapse the corporate structure. ${ }^{165}$ This subjective focus leads to inconsistencies in the manner in which the veilpiercing doctrine is applied. ${ }^{166}$

In contrast, this Article's balancing test starts with the existence of material improprieties but then provides a more objective foundation-that of economic efficiency-for the doctrine. Admittedly, however, a balancing test can be difficult to apply. Sometimes the harm and benefits cannot be easily quantified. Furthermore, because veil-piercing could hurt legitimate creditors of the parent firm, the balancing is delicate. This delicacy is compounded because the mere possibility of a judge piercing the corporate veil adds uncertainty to credit markets by reducing reliance on contractual and corporate arrangements. A practical solution is suggested, however, by the substantive-consolidation jurisprudence.

Substantive consolidation likewise balances benefit and harm. Similarly, the mere possibility of a judge imposing substantive consolidation in bankruptcy adds uncertainty to credit markets by reducing reliance on pre-bankruptcy contractual and corporate arrangements. Therefore, to minimize mistakes and market disrup-

159. See supra note 113 and accompanying text (discussing what should constitute material improprieties).

160. See supra note 70 and accompanying text.

161. See supra Part II.E.

162. See supra note 104 and accompanying text (defining net harm). This balance can be even further refined because most of a firm's voluntary creditors can protect themselves from harm, such as by adjusting their rates of interest. See supra note 55 (defining non-adjusting creditors). Externalities imposed on those voluntary creditors therefore should be insufficient to invoke piercing of the corporate veil. Thus, one need focus only on the harm to non-adjusting creditors.

163. See supra note 27 and accompanying text.

164. Id.

165. Cf. Cox, supra $19, \S 7.08$ at $280-81$ ( $2 \mathrm{~d}$ ed. 2003) (listing factors and improprieties to be taken into account in veil-piercing analysis and stating, "the more factors that are present, the more likely it is that a court will disregard the veil of limited liability").

166. See supra note 28 and accompanying text. 
tion, courts graft a "heavily-outweigh" standard onto the balancing test, imposing substantive consolidation only where the benefits of consolidation heavily outweigh its harm. ${ }^{167}$

Veil-piercing jurisprudence similarly would become more pragmatic and attain greater predictability by using a modified balancing test inspired by the "heavilyoutweigh" standard used in substantive consolidation. To this end, I propose that the "net harm" requirement of the Rule-measured by whether the aggregate harm caused by the structure exceeds the structure's aggregate benefit-be replaced by a "manifest net harm" requirement, measured by whether the aggregate harm caused by the structure manifestly exceeds the structure's aggregate benefit. ${ }^{168}$ Thus, a corporate structure should be respected, and the contracting parties should not be liable, unless the structure (x) thwarts or significantly impairs legislative policies, or $(y)$ has material improprieties and causes either manifest net harm or intentional externalities.

Admittedly, this compromise to the Rule, like any other compromise, is imperfect. There may be some sacrifice of integrity because, as discussed below, the "manifest net harm" standard pushes the margin away from collapsing corporate structures, which in turn can lead to preserving some structures that otherwise should be collapsed. ${ }^{169}$ The compromise is needed, however, because KaldorHicks efficiency is difficult to assess in real life. The compromise's imperfections are also mitigated because the Rule would collapse a corporate structure with material improprieties, even without a finding of manifest net harm, where the contracting parties intend the structure to cause externalities. ${ }^{170}$

Intentionality, however, raises two issues: What does it mean for a firm, as opposed to a natural person, to have intent to harm creditors; and what does intent to harm creditors mean in a legal system that generally condones corporate limited liability? The first question is present in any corporate context where intent is at issue, and its resolution in those other contexts should be equally relevant here. ${ }^{171}$ I therefore focus on answering the second question.

Everyone would agree that malicious intent to harm creditors should trigger collapse of a corporate structure in order to protect those creditors; but what if parties contract without malicious intent but with awareness that harm may re-

167. See infra note 189 and accompanying text (discussing the "heavily-outweigh" standard). Without this standard, a balancing test might be difficult to apply, given that the contracting parties include the firm, its subsidiaries, and stockholders. Adjusting creditors also are contracting, in a sense, but it is presumed that they will neither gain nor lose but simply adjust their yield to preserve their rights. See supra note 162.

168. This is, of course, a slightly different approach than that of substantive consolidation. Whereas substantive consolidation jurisprudence balances the benefits of collapsing the corporate structure against the harm of collapsing that structure, the Rule balances the aggregate benefit against the aggregate harm of preserving the corporate structure.

169. See infra note 189 . Whether, in those circumstances, the externalities should be internalized through liability rather than by collapsing the structure is beyond this Article's scope.

170. Recall that the second step of the inquiry requires an additional finding of either manifest net harm or intentional externalities.

171. This is essentially an agency question. See, e.g., JefFrey D. Bauman et al., Corporations Law AND POLICY 366-73 (5th ed. 2003). 
sult? In a legal system that generally condones corporate limited liability, but where firms can fail, the contracting parties will know that any corporate structure, including theirs, creates some risk of harm to creditors. Should that awareness be regarded as intent? I believe that contracting that creates only a low probability of third-party harm should not be regarded as intentionally harmful. Otherwise, the intentionality standard and corporate limited-liability would conflict, ${ }^{172}$ and no corporate structure would ever be safe from challenge because virtually all contracts create the potential for externalities. ${ }^{173}$

The more difficult question is whether contracting that creates a high probability of third-party harm should be regarded as intentionally harmful. The tort law of nuisance suggests an answer. Its intentionality requirement ${ }^{174}$ is satisfied not only by malicious intent but also "merely in the sense that the defendant has created or continued the condition causing the interference with full knowledge that the harm to the plaintiff's interests [is] substantially certain to follow." 175 A substantial-certainty test is equally appealing as a proxy to satisfy the intentionality requirement for collapsing corporate structures. To appreciate why, consider a parent-firm leasing assets to an undercapitalized subsidiary that engages in a highrisk business, where the parent knows it is substantially certain that third parties will be injured by the subsidiary's actions but unable to recover. If the relationship between the parent and its subsidiary has material improprieties, collapsing the structure to allow the subsidiary's creditors to get at the parent-firm's assets clearly seems appropriate. ${ }^{176} \mathrm{~A}$ court applying the substantial-certainty proxy for intent will be able to collapse that structure.

That leaves open, though, the question of how it is possible to prove knowledge itself, the parent-firm's actual state of mind. Sometimes that may be gleaned from depositions or cross-examination, but often it will be subjective and unascertainable. Here again, tort law suggests an answer. Tortious interference with contract occurs not only where a party knows, but increasingly also where it should have known, that its actions will interfere with a third party's contract. ${ }^{177}$ This proxy for knowledge is objectively ascertainable, and there is little reason to protect a party that should have known the consequences of its actions. This Article likewise proposes, in the context of collapsing corporate structures, that a court

172. See supra note 155 and accompanying text (discussing limited liability).

173. See supra note 80 and preceding text (observing that the mere existence of externalities should not necessarily defeat contract enforcement because many contracts create externalities).

174. See supra note 153 and accompanying text (indicating this requirement).

175. Prosser \& KeETON, supra note 121 , at 625

176. See supra note 23 and accompanying text.

177. See, e.g., Prudential Real Estate Affiliates, Inc. v. Long \& Foster Real Estate, Inc., 208 F.3d 210, No. 99-1357, 2000 WL 248170, at*4 (4th Cir. Mar. 6, 2000) (rejecting defendant's argument that it did not know about a franchise agreement's restrictions on the sale of a business because "a factfinder could reasonably infer from [the] evidence that [defendant] knew or should have known of the terms of "that agreement); $c f$. RESTATEMENT (THIRD) OF AGENCY $\S 5.30$ (Tentative Draft No. 4, 2003) (imputing to the principal notice of a fact "that an agent knows or has reason to know"); DAN B. DOBBS, THE LAW OF TORTS $\S 452$, at 1285 (2000) (discussing New Jersey Supreme Court's reasoning that defendant would owe a duty of reasonable care to protect against economic harm where defendant "knew or had reason to know that such harm was likely."). 
should be able to infer knowledge in cases where the parent should have known that harm was substantially certain to occur. ${ }^{178}$

Given these modifications, a corporate structure should be respected, and the contracting parties should not be liable, unless the structure (x) thwarts or significantly impairs legislative policies, or (y) has material improprieties and either the structure causes manifest net harm or the parties know or should know that the structure is substantially certain to cause harm.

\section{Substantive Consolidation}

I next apply the Rule to the doctrine of substantive consolidation. The first inquiry is whether the corporate structure being considered for consolidation would thwart or significantly impair any legislative policies. Because substantive consolidation is a bankruptcy-law doctrine and applies only in the bankruptcy context, ${ }^{179}$ the applicable policies here are those of bankruptcy.

Three fundamental policies underlie bankruptcy law: equality of distribution among creditors, debtor rehabilitation, and economical administration of the bankruptcy process. ${ }^{180} \mathrm{~A}$ corporate structure is unlikely to thwart or significantly impair the policy of equality of distribution. Although substantively consolidating, or combining, the assets and liabilities of affiliated firms often may create greater absolute equality among creditors, the policy of equality of distribution (like bankruptcy law itself) generally respects contractual inequalities arising out of pre-bankruptcy entitlements, ${ }^{181}$ including corporate separateness. ${ }^{182}$ A corporate structure also is unlikely to thwart or significantly impair the policy of debtor rehabilitation. After all, there is no assurance, ex ante, that a substantivelyconsolidated corporate structure would function any more effectively than the original structure. Lastly, although consolidating the assets and liabilities of affiliated firms might reduce the cost of bankruptcy administration, bankruptcy law already reduces that cost without needing to impose substantive consolidation. It does this by procedurally—but not substantively-consolidating affiliated bank-

178. This inference could well explain why some courts are willing to pierce the corporate veil based on a combination of material improprieties and significant undercapitalization: in those cases, the undercapitalization itself effectively becomes a proxy for intent.

179. See In re Augie/Restivo Baking Co., 860 F.2d 515, 518 n.1 (2d Cir. 1988). "Courts have found the power to consolidate substantively in the court's general equitable powers as set forth in 11 U.S.C. $\S 105^{\prime \prime}$ of the federal Bankruptcy Code. Id. Although each of the other doctrines discussed in this Article could be applied in a bankruptcy case, those other doctrines are products of non-bankruptcy law.

180. See Schwarcz, Rethinking Freedom of Contract: A Banknuptcy Paradigm, supra note 73, at 542-43.

181. Douglas G. Baird, Bankruptcy's Uncontested Axioms, 108 YALE L.J. 573, 578 (1998).

182. See, e.g., Augie/Restivo Baking Co., 860 F.2d at 518 (refusing to substantively consolidate a corporate structure on which certain creditors relied, even though those creditors would have priority distribution, because " $[t]$ he sole purpose of substantive consolidation is to ensure the equitable treatment of all creditors."); Eastgroup Props. v. S. Motel Ass'n, Lid. 935 F.2d 245, 248 (11th Cir. 1991) (stating that " $[\mathrm{t}]$ he purpose of substantive consolidation is to insure the equitable treatment of all creditors.") (quoting In re Murray Indus., 119 B.R. 820, 830 (Bankr. M.D. Fla. 1990)) 
ruptcy cases. ${ }^{183}$ In general, therefore, a corporate structure should not thwart or significantly impair any bankruptcy policy.

The next inquiry is whether the corporate structure in question has material improprieties and, if so, whether the structure would cause either manifest net harm or the parties know or should know that the structure is substantially certain to cause harm. The actual substantive-consolidation jurisprudence effectively begins with this same inquiry: whether there is a substantial breakdown of corporate formalities between the firms being considered for consolidation. ${ }^{184}$ Where there is such a breakdown, the substantive-consolidation jurisprudence turns to a balancing test, which weighs the benefits of collapsing the corporate structure (through substantive consolidation) against the harm of collapsing that structure. That approach is not dissimilar to this Article's "efficiency" focus on net harm (though the substantive-consolidation jurisprudence does not explicitly tie its balancing test to economic theory). ${ }^{185}$ Logically, then, one would expect a court to substantively consolidate two firms where the benefit of collapsing the corporate structure outweighs the harm of collapsing that structure. ${ }^{186}$

However, because substantive consolidation could hurt third-party creditors of the more solvent firm (albeit benefiting third-party creditors of the less-solvent firm), the balancing is delicate. ${ }^{187}$ This delicacy is compounded because the mere possibility of a judge imposing substantive consolidation in bankruptcy adds uncertainty to credit markets by reducing reliance on contractual arrangements. ${ }^{188}$ Therefore, to minimize mistakes and market disruption, courts graft a "heavilyoutweigh" standard onto the balancing test, imposing substantive consolidation only where the benefits of consolidation heavily outweigh its harm. ${ }^{189}$ For similar reasons, as discussed, ${ }^{190}$ that approach has inspired this Article's adoption of a "manifest net harm" standard.

183. See, e.g., In re Flora Mir Candy Corp., 432 F.2d 1060, 1062 (2d Cir. 1970) (distinguishing substantive from procedural consolidation under FED. R. CIV. P. 42(a)).

184. See supra note 32 and accompanying text.

185. This Article's concept of net harm derives from Kaldor-Hicks efficiency. See supra notes 9295 and accompanying text. Another possible distinction between these tests is that substantive consolidation purports to be concerned only with the equitable treatment of creditors (see supra note 182); and thus the balancing test thereunder would be expected to weigh only benefit and harm to creditors, ignoring any benefit to the contracting parties. As articulated, however, that test does not appear to be so limited. See, e.g., Eastgroup Props., 935 F.2d. at 249.

186. This assumes, of course, the existence of material improprieties. Substantive-consolidation jurisprudence also requires that creditors of the more solvent firm relied on that firm's corporate separateness, which is almost always the case. Id. at 251.

187. Cf. supra note 35 and accompanying text (discussing the effect of substantive consolidation on creditors of firms with differing debt-equity ratios).

188. Kors, supra note 30, at 446. Bankruptcy law, as discussed, generally recognizes pre-bankruptcy contractual arrangements in order to minimize uncertainty. See supra note 181 and accompanying text.

189. Eastgroup Props., 935 F. 2 d at 249. Presumably given the importance of avoiding mistakes and market disruption, courts do not appear to be concerned that the heavily-outweigh standard pushes the margin away from a finding a substantive consolidation, thereby preserving some corporate structures that otherwise would be collapsed.

190. See supra note 168 and accompanying text. 
There is, however, a significant difference between substantive consolidation law and the Rule: The former pays little if any attention to intent to cause harm, whereas the latter would sometimes collapse structures based on that intent. This difference in part reflects different underlying rationales. The authority of substantive consolidation law derives from a bankruptcy judge's equitable powers, ${ }^{191}$ and courts have worried that harming even one innocent creditor who relied on the limited-liability rule of corporation law ${ }^{192}$ might violate equity ${ }^{193}$-a harm that may well occur if a corporate structure is collapsed for intent. In contrast, the underlying rationale of the Rule is economic efficiency, which (in its Kaldor-Hicks form) recognizes that decisions sometimes must be made that harm some for the benefit of other objectives. ${ }^{194}$ Furthermore, the "material improprieties" requirement of the Rule provides a signal to creditors that the structure could be collapsed, reducing their reliance on the structure and minimizing their harm if collapse occurs. ${ }^{195}$

\section{Recharacterizing Sales}

As discussed, the matter of recharacterizing sales as transfers intended for security (i.e., secured loans) is most clearly at issue in the context of securitization. In that context, the Rule predicts precisely, and adds insight into, the arguments raised by courts and commentators.

The Rule's first inquiry is whether the securitization sale contract at issue would thwart or significantly impair legislative policies. If all transactions characterized by contract as securitization sales were enforced as such, securitization indeed could be used in lieu of secured financing as a means of thwarting certain basic bankruptcy-law remedies. ${ }^{196}$ This is because a securitization sale transfers title to the "collateral" to the SPV, thereby obviating a firm's ability in bankruptcy to use cash collateral as working capital for its reorganization ${ }^{197}$ or to raise reorganization financing by granting to new lenders a lien on collateral that is pari passu with or, if needed, having priority over pre-petition liens on the same collateral. ${ }^{198}$

191. 11 U.S.C. $\S 105$ (2000).

192. See supra note 187 and accompanying text.

193. In re Augie/Restivo Baking Co., 860 F.2d 515 (2d Cir. 1988).

194. Cf. Kaplow \& Shavell, supra note 90 , at 1015 (arguing it is infrequent that a policy is under consideration that will make all parties better off).

195. See supra notes $108-109$ and accompanying text.

196. Structured FinANCE, supra note 32, at 4-3 to 4-5; cf. Peter Pantaleo et al., Rethinking the Role of Recourse in the Sale of Financial Assets, 52 Bus. Law. 159, 186 (1996); but cf. Schwarcz, Securitization Post-Enron, supra note 40, at 1574 (arguing that, as actually practiced, securitization facilitates bankruptcy policy).

197. See 11 U.S.C. $\$ 363(2000)$

198. Id. $\S 364$ (c) (noting pre-petition liens being liens or security interests granted by the firm prior to the filing of its bankruptcy petition). This assumes the holder of the original collateral receives adequate protection. "Adequate protection" is not defined in the Bankruptcy Code. Instead, section 361 of the Bankruptcy Code provides examples of what may constitute adequate protection, such as making periodic cash payments to the creditor (section $361(1)$ ) or granting a lien on other unencumbered property of the firm (section 361(2)), and leaves it for the courts to decide on a case-by-case basis what constitutes "adequate protection" in the circumstances. See, e.g., In re Timbers of Inwood Forest Assocs., Ltd., 808 F.2d 363, 363 (5th Cir. 1987), aff'd, 484 U.S. 365 (1988); In re AIC Indus., Inc., 83 B.R. 774, 777 (Bankr. D. Colo. 1988); In re O.P. Held, Inc., 74 B.R. 777, 782-84 (Bankr. N.D.N.Y. 1987). 
For example, in the bankruptcy case of In re LTV Steel Co. ${ }^{199}$ LTV challenged its pre-bankruptcy securitization facilities, arguing that the securitization transfers to the SPVs were not true sales and, therefore, that LTV should be able to use the collections of financial assets as "cash collateral" by giving adequate protection under bankruptcy law. LTV's rationale was that, without such use, it might have to cease its operations, thereby jeopardizing employee jobs and retiree benefits and adversely affecting the local economy. The bankruptcy court permitted LTV to use these collections pending resolution of the true sale issue. ${ }^{200}$

Because of this potential to thwart bankruptcy remedies, courts have articulated factors to differentiate sales from secured loans and, based on these factors, have recharacterized certain purported sale structures as secured loans. ${ }^{201}$ So far this parallels the Rule, which would recharacterize a sale structure in order to prevent securitization from thwarting or significantly impairing legislative policies.

The second inquiry under the Rule is whether the applicable securitization-sale structure has material improprieties and, if so, whether it causes manifest net harm or the parties know or should know that it is substantially certain to cause harm. Putting aside for the moment the question of material improprieties, ${ }^{202} \mathrm{I}$ focus first on the issue of net harm.

There has been a backlash by certain scholars against securitization on the supposition that it creates externalities by harming a firm's non-adjusting creditors. ${ }^{203}$ Uncertainty over the amount of harm may partially account for the muddled state of the law of recharacterizing sales. ${ }^{204}$ Recent research shows, however, that the harm to non-adjusting creditors caused by securitization should be nonmaterial, and indeed is likely to be zero or even negative. ${ }^{205}$ Although individual non-adjusting creditors sometimes will be harmed by securitization transactions, that harm should be more than offset for non-adjusting creditors as a class by the benefits of securitization. ${ }^{206} \mathrm{~A}$ fortiori, given that the contracting parties expect to

199. 274 B.R. 278 (Bankr. N.D. Ohio 2001).

200. Id. at $280,285-86$. That case, however, "should have little importance as a legal precedent because, prior to such resolution, the parties reached a settlement that included a summary finding that the transfers were true sales." STRUCTURED FINANCE, supra note 32, at 4-4.

201. See, e.g., STRUCTURED FINANCE, supra note 32 , at 4-6 to 4-12 (differentiating by reference to the amount and nature of recourse, the existence of retained rights and rights to any surplus, the pricing mechanism, and the administration and collection of accounts).

202. I later discuss this question. See infra notes $211-213$ and accompanying text.

203. See Lois R. Lupica, Asset Securitization: The Unsecured Creditor's Perspective, 76 TEx. L. REv. 595, 659 (1998); Edward J. Janger, Muddy Rules for Securitizations, 7 FORDHAM J. CORP. \& Fin. L. 301, 306 (2002); see also Bebchuk \& Fried, supra note 55, at 869-70 (originally raising this uneasiness in the context of examining the efficiency and distributional consequences of secured lending); but $c f$. Schwarcz, Securitization Post-Enron, supra note 40, at 1570-71 (arguing that securitization does not harm non-adjusting creditors).

204. Cf. Part III.C (Internalizing Externalities), attempting to resolve this issue.

205. See Schwarcz, Securitization Post-Enron, supra note 40, at 1569 (analyzing the impact of securitization on unsecured and non-adjusting creditor classes, and concluding that its harm should be non-material and indeed is likely to be zero or even negative).

206. Id. at 1570 (arguing that although individual non-adjusting creditors sometimes will be harmed where an originator that overinvests securitization proceeds later goes bankrupt, this harm must be weighed against benefits that stem from a lower interest-cost burden and improved liquidity). 
benefit from securitization, ${ }^{207}$ any net harm should be non-material (and perhaps even zero or negative). ${ }^{208}$ Therefore, securitization structures should not cause manifest net harm.

Absent net harm, the remaining inquiry under the Rule is whether the contracting parties engage in securitization intentionally to cause harm. Though one commentator has made that allegation, ${ }^{209}$ others have soundly refuted it. ${ }^{210}$ Intentional harm therefore appears unlikely.

Externalities alone therefore do not justify recharacterizing securitization sale contracts. Accordingly, there is no need, under the Rule, to analyze whether securitization-sale structures contain material improprieties. ${ }^{211}$ The muddled state of the recharacterizing-sales jurisprudence nonetheless may reflect, in addition to uncertainty over the amount of harm, ${ }^{212}$ that judges have at least implicitly grappled with the issue of improprieties. Although improprieties would be expected to be rare because securitization-sale contracts are arm's-length negotiated agreements, some courts might infer the existence of improprieties simply because a securitization-sale structure bears some economic or other similarity to a secured loan-even though the structure does not bear a greater resemblance to a secured loan than a sale. ${ }^{213}$ Under the Rule, those improprieties should be irrelevant.

\section{Collapsing LBO Transactions}

Applying the Rule to these transactions, the first inquiry is whether respecting LBO structures would thwart or significantly impair legislative policies. Although there might be arguments to the contrary, ${ }^{214}$ it does not appear that LBO transactions thwart or impair any such policies. Some LBO transactions could be

207. See supra note 70 and accompanying text.

208. This reflects that net harm, as the term is used in this Article, is a Kaldor-Hicks concept, comparing aggregate harm to aggregate benefit.

209. See Lynn M. LoPucki, The Death of Liability, 106 YALE L.J. 1, 30 (1996) (alleging that "[a]sset securitization may be the silver bullet capable of killing liability."); Lynn M. LoPucki, The Irrefutable Logic of Judgment Proofing: A Reply to Professor Schwarcz, 52 STAN. L. REV. 55 (1999).

210. See, e.g., White, supra note 24; Schwarcz, The Inherent Irrationality of Judgment Proofing, supra note 20; Charles W. Mooney, Judgment Proofing, Bankruptcy Policy, and the Dark Side of Tort Liability, 52 STAN. L. Rev. 73 (1999); Steven L. Schwarcz, Judgment Proofing: A Rejoinder, 52 STAN. L. Rev. 77 (1999). Although certain of Enron's structured transactions were alleged to be non-arm's length "sham transactions that have no legitimate business purpose and mislead investors, analysts, and regulators about companies' activities, tax obligations, and true financial condition" (SENATE PERMANENT SUb-

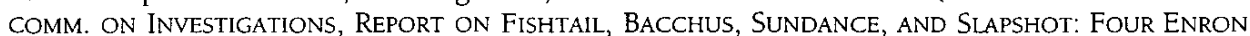
TRANSACTIONS Funded and Faclititated by U.S. FinanCial Institutions, S. Rep. No. 107-82, at 2 (2003), available at http://govt-aff. senate.gov/010203psireport.pdf (last visited Oct. 1, 2004)), those transactions were not securitization transactions. See Schwarcz, Enron and the Use and Abuse of Special Purpose Entities in Corporate Structures, supra note 1, at 1315-16.

211. That need is obviated because, irrespective of any such improprieties, the securitization-sale structure does not cause net harm.

212. See supra note 204 and accompanying text.

213. See supra note 8 and accompanying text.

214. Possible contrary arguments might pertain to the fairness of LBO transactions to shareholders (cf. Gregory J. Schwartz, Regulation of Leveraged Buyouts to Protect the Public Shareholder and Enhance the Corporate Image, 35 CATH. U. L. REV. 489 (1986)) or the implications of LBO transactions for tax policy (cf. Patricia L. Bryan, Leveraged Buyouts and Tax Policy, 65 N.C. L. REv. 1039 (1987)). 
viewed as inconsistent with legislative policy under fraudulent conveyance law, but those transactions would be subject to avoidance under that law.215 Once voided, they neither would thwart nor impair that policy. To this extent, the Rule predicts existing jurisprudence.

The next inquiry is whether a given LBO structure has material improprieties and, if so, whether it causes manifest net harm or the parties know or should know that it is substantially certain to cause harm. The potential for impropriety arises where the LBO causes the target firm to become insolvent, leading to its failure. In fact, the actual LBO jurisprudence identifies this type of impropriety as a basis to collapse an LBO structure in order to undo the priority of the LBO lender. ${ }^{216}$

Mere impropriety, however, is insufficient under the Rule to justify collapse. The Rule would collapse an LBO structure only if, in addition to the impropriety, the structure causes manifest net harm or the parties know or should know that it is substantially certain to cause harm. Consider first net harm. Admittedly, a failed LBO harms the claims of the target firm's existing creditors. ${ }^{217}$ Courts, though, have not yet explicitly gone the extra step contemplated by the Rule, attempting to balance that harm against any benefits of engaging in LBO transactions. Those benefits can be significant, including the premium received by the target firm's shareholders. ${ }^{218}$ They also might include a range of intangible policy benefits. ${ }^{219}$

Because of these intangibles, it can be especially difficult to assess the existence of net harm in the context of LBO transactions. Even the proposed "manifest net harm" standard might not necessarily help. Perhaps implicitly for this reason, in the one case actually collapsing an LBO structure the court collapsed only the portion of that structure involving the LBO lender's collateral. ${ }^{220}$ Such a partial collapse would preserve most of the benefits of the LBO transaction, including the premium received by the target firm's shareholders and the intangible policy benefits, while also mitigating the harm to the target firm's creditors. ${ }^{221}$ This represents a practical variation on this Article's balancing test.

215. See 11 U.S.C. $\$ 548(2000)$.

216. U.S. v. Tabor Court Realty Corp., 803 F.2d 1288, 1296 (3rd Cir. 1986) (looking to whether the LBO lender knew or should have known that the LBO structure would lead to insolvency).

217. See supra notes 55-56 and accompanying text (observing that because borrowed LBO funds add to the target firm's overall debt burden without increasing its assets, and in many cases existing claims are also effectively subordinated to claims of the LBO lender, existing creditors are prejudiced if the target firm becomes insolvent or goes bankrupt).

218. See supra note 51 and accompanying text.

219. See Baird \& Jackson, supra note 3 , at 853 (arguing that LBO "transactions do not seem to be clearly to the detriment of creditors .... With the buyout may come more streamlined and more effective management. Among other things, a going-private transaction may save the costs of complying with relevant federal securities statutes.").

220. Supra notes 63 and 216 and accompanying text. Cf. POSNER, ECONOMIC ANALYSIS OF LAW, (6th ed.), supra note 91 , at 25 ("[F]ew judicial opinions contain explicit references to economic concepts [but] [i]t would not be surprising to find that many legal doctrines rest on inarticulate gropings toward efficiency").

221. The harm to the target firm's creditors would be mitigated because their claims now become pari passu with the claim of the LBO lender, whose collateral has been invalidated. They still would be harmed, however, in their capacity as creditors of the now-insolvent target firm. 
Even absent net harm, the Rule would collapse an LBO structure with material improprieties where the contracting parties know or should know that the structure is substantially certain to cause harm. That scenario, however, is unlikely as a practical matter. LBO transactions require lenders to put significant amounts of their money at risk. ${ }^{222}$ To avoid litigation, LBO lenders already go to great lengths to ensure that the target firm's creditors are not harmed. It is, for example, standard and customary for such lenders to insist on independent analyses from reputable independent valuation firms that, after giving effect to the LBO, the target firm will be solvent, able to pay its debts, and adequately capitalized. ${ }^{223}$ When undertaken, this due diligence provides the lender a defense. Similarly, under the Rule, the due diligence would obviate a finding of intent to cause harm.

\section{Conclusions}

This Article attempts to answer one of the most fundamental questions in corporate law: When is a corporate structure legitimate, and when should it be collapsed? Although judges and scholars have attempted to answer this question in isolated doctrinal contexts, they have not seen the question as cutting across doctrines or attempted to formulate rules of general application, much less an overall theory from which to derive such rules. This failure leaves the law with unsettling ad hocery, which in turn creates uncertainty, inconsistency, and inefficiency on multiple levels.

Collapsing or recharacterizing a corporate structure involves collapsing or recharacterizing the corporate contractual arrangements that constitute the structure. Because the raison d'etre of contracting is efficiency, externalities should be allowed to defeat contract enforcement only where they cause the contracting in question to become economically inefficient. ${ }^{224}$ Although the real-world operating standard of efficiency is Kaldor-Hicks, that standard may be insufficient because it takes externalities into account only in the aggregate balancing of benefit and harm. A Pareto efficiency standard, however, would fail because virtually all corporate structures are, to some extent, subject to non-internalized externalities.

This Article therefore employs a two-step analysis. First, it uses a Kaldor-Hicks standard of efficiency for collapsing (inefficient) corporate structures; second, it examines the extent to which, notwithstanding Kaldor-Hicks efficiency, corporate structures should be collapsed (or other remedies provided) in order to internalize externalities. This approach resolves the dilemma that neither Kaldor-Hicks effciency nor Pareto efficiency alone provides an adequate standard. ${ }^{225}$

Utilizing this approach, the Article first argues that a corporate structure should be legitimate-meaning that the structure should be respected, and contracting

222. See supra note 48 .

223. Schwarcz, Rethinking a Corporation's Obligations to Creditors, supra note 48, at 685 .

224. The Article also argues that contract enforcement should be defeated where the corporate structure itself thwarts or significantly impairs a legislative policy. Rarely, however, does a corporate structure have that impact.

225. See supra notes 87-102 and accompanying text. 
parties should not be liable for harm caused by the structure 226 - unless the structure (x) thwarts or significantly impairs legislative policies, or (y) has material improprieties and causes either net harm (meaning that, taking into account externalities, the aggregate harm of the structure exceeds its aggregate benefit) or intentional externalities. The underlying rationale for this proposed rule is that allowing Kaldor-Hicks efficient freely-negotiated corporate structures that internalize intentional externalities should be the socially optimal result even though the failure to internalize unintentional externalities may discourage some market participants at the margin.

The Article then tests this rule by applying it to various doctrines under which courts have actually collapsed or recharacterized corporate structures. The rule helps explain and interrelate these doctrines, adding predictability and conceptual justification to the jurisprudence of piercing the corporate veil; explaining the relationship between, and providing a basis to harmonize, that doctrine and the doctrine of substantive consolidation; and providing conceptual guidance and clarity to the doctrines of collapsing LBO transactions and distinguishing loans from sales.

The testing also reveals that the rule would benefit from several practical modifications. Determining the existence of net harm can be difficult, and would be even more difficult where collapsing or recharacterizing a corporate structure would hurt legitimate creditors who relied on the structure. This difficulty is compounded because the mere possibility of a judge collapsing or recharacterizing the structure adds uncertainty to credit markets. To minimize mistakes and market disruption, the Article proposes that the rule's "net harm" requirement be restated as a "manifest net harm" requirement, measured by whether the aggregate harm caused by the structure manifestly exceeds the structure's aggregate benefit. This approach to proving net harm has precedent in related areas of law where it is likewise important to minimize mistakes and market disruption.

Thus, a corporate structure should be respected, and the contracting parties should not be liable, unless the structure $(x)$ thwarts or significantly impairs legislative policies, or (y) has material improprieties and causes either manifest net harm or intentional externalities. To mitigate the burden of proving intent, the Article proposes that intent be inferred where the contracting parties know or should know that the structure is substantially certain to cause harm-an approach that has precedent in related areas of law where it is likewise important to strive for an objective standard of intentionality.

One might ask whether this rule provides better guidance than existing jurisprudence. I believe it does, and it certainly should not provide less guidance given the confused and inconsistent state of that jurisprudence. Furthermore, even if courts are unwilling to adopt the rule as it stands, it still should have value as a conceptually-grounded model from which judges can discern the types of issues

226. Courts sometimes may, and in order to minimize externalities to innocent creditors perhaps sometimes should, prefer a lesser remedy than collapsing a problematic corporate structure - such as imposing liability on the parties who created the structure. Nothing in this Article is meant to suggest that such a lesser remedy may not sometimes be appropriate. 
and nuances they should be grappling with in order to determine which corporate structures are legitimate and which should be collapsed.

The rule, and its derivation, also suggest an answer to what has been described as a "major conceptual problem" of contract law: determining which externalities are to count in constraining the ability of parties to contract with each other. ${ }^{227}$ In deriving the rule, I confronted this problem in the limited context of corporate contracts. I attempted to solve that problem from first principles, however, and did not need to address particularities of corporation law other than to impose a requirement that any corporate structure being collapsed must have material improprieties. That requirement, though, was needed principally to harmonize the rule with the limited-liability rule of corporation law. ${ }^{228}$ In a non-corporate context, therefore, a material-improprieties requirement should be unnecessary. Accordingly, the externalities that are to count in constraining the ability of parties to contract with each other, this Article implicitly argues, are those that (i) a contracting party knows or should know are substantially certain to cause material harm to third parties, ${ }^{229}$ or (ii) cause harm that manifestly exceeds the aggregate benefit of the contracting. ${ }^{230}$

Because most of a corporate structure's externalities result from the limitedliability rule of corporation law, ${ }^{231}$ it is useful in closing to examine how this Article's analysis might inform, or be informed by, the long-standing debate over that rule. ${ }^{232}$ That debate remains unresolved because limited liability "has costs as well as benefits, and those costs and benefits are sometimes in close balance."233

This Article only indirectly informs that debate. Although both limited liability and collapsing corporate structures ultimately turn on the question of economic efficiency in the face of externalities, any resolution of the limited-liability debate appears intractable, requiring empirical evidence of whether the benefits of limitedliability exceed its costs (such costs principally constituting externalities arising

227. See supra note 68 and accompanying text.

228. See supra notes 107-111 (discussing the material improprieties requirement).

229. The materiality qualification is implicit in this Article's use of the term "extemalities." See supra note 83 (stating that references to "externalities" mean externalities that satisfy the minimum threshold of causing material harm).

230. This clause (ii) follows the definition of manifest net harm. See supra note 168 and accompanying text.

231. See supra note 132 and accompanying text. Limited liability, the default rule in corporation law, means that shareholders of a firm are generally not liable for debts of the firm. Collapsing a corporate structure may collapse the limited-liability scheme associated with that structure. See supra Parts II.A and II.B.

232. For a history of that debate, see Callison, supra note 66; Hansmann \& Kraakman, Toward Unlimited Shareholder Liability for Corporate Torts, supra note 19; Larry E. Ribstein, Limited Liability and Theories of the Corporation, 50 MD. L. REV. 80 (1991); Susan E. Woodward, Limited Liability in the Theory of the Firm, 141 J. INST. \& THEORETICAL ECON. 601 (1985); Easterbrook \& Fischel, supra note 15; Paul Halpern et al., An Economic Analysis of Limited Liability in Corporation Law, 30 U. TORONTO L.J. 117 (1980); cf. William W. Bratton \& Joseph A. McCahery, An Inquiry into the Efficiency of the Limited Liability Company: Of Theory of the Firm and Regulatory Competition, 54 WASH. \& LEE L. REV. 629 (1997).

233. Henry Hansmann \& Reinier Kraakman, The Essential Role of Organizational Law, 110 YALE L.J. 387, 423 (2000) [hereinafter Hansmann \& Kraakman, The Essential Role of Organizational Law]. 
from the incentives that limited-liability creates for opportunistic behavior). ${ }^{234}$ In contrast, my analysis of collapsing corporate structures only needs to assume the existence of limited liability as the default rule-an assumption that reflects the reality of the world as we know it. ${ }^{235}$ This makes the analysis more tractable, asking only when, in individual cases, the corporate structure (and thus limited liability) should be collapsed. That question is answerable because the claims of the relevant parties, including creditors - and thus the consequences of collapsing the structure-will be reasonably quantifiable if not known. ${ }^{236}$

234. Hansmann \& Kraakman, Toward Unlimited Shareholder Liability for Corporate Torts, supra note 19 , at 1879. "The question [of whether limited liability should be preserved] remains open chiefly because the merits of limited liability depend ... on empirical issues that are difficult to resolve on the basis of available evidence." Id at 1880 . For a detailed discussion of those incentives that limited liability creates for opportunistic behavior, see id.; see also Hansmann \& Kraakman, The Essential Role of Organizational Law, supra note 233, at 423 (observing that the costs of limited liability "derive principally from the possibilities it creates for the firm's owners to act opportunistically toward business creditors."); Callison, Rationalizing Limited Liability and Veil Piercing, supra note 66, at 1063 (observing that "[l]imited liability protections create incentives for excessive risk taking by permitting firm owners to avoid the full costs of their business activities while reaping the full economic reward of such activities.").

235. Hansmann \& Kraakman, Toward Unlimited Shareholder Liability for Corporate Torts, supra note 19 , at 1879 (observing that "[l]imited liability . . has been the prevailing rule for corporations in the United States, as elsewhere, for more than a century."). Building a normative case on a foundation of unexamined assumptions has weighty precedent. See, e.g., Hansmann \& Kraakman, The Essential Role of Organizational Law, supra note 233, at 391 (noting that although "[e]conomic theory does not offer a completely satisfactory explanation for the fact that productive activity is commonly organized in the form of large nexuses of contracts, in which a single central actor contracts simultaneously with employees, suppliers, and customers who may number in the thousands or even millions .... [W] will not delve into [that subject] here. Rather, we will simply take it for granted . . . "); Lucian Arye Bebchuk, A New Approach to Corporate Reorganizations, 101 HaRv. L. Rev. 775, 776-77 (1988) (assuming without examination the existence (and significant use) of the reorganization alternative to liquidation; and analyzing the best method for dividing the reorganization pie).

236. One might ask why, if this Article's analysis starts with the implicit assumption that limited liability is the norm, that assumption sometimes is challenged. The Article helps to provide an answer: although allowing wholesale challenges would undermine contractual expectations, the existence of material improprieties in an underlying corporate structure provides a signal to third parties that this assumption may be challenged for that particular structure. See supra notes 108-109 and accompanying text. 
